\title{
Fluvio-deltaic floodbasin deposits recording differential subsidence within a coastal prism (central Rhine-Meuse delta, The Netherlands)
}

\author{
K.M. COHEN, M.J.P. GOUW and J.P. HOLTEN \\ Centre for Geo-ecological Research (ICG), Department of Physical Geography, Utrecht University, \\ P.O. Box 80.115, 3508 TC Utrecht, The Netherlands (Email: k.cohen@geog.uu.nl)
}

\begin{abstract}
In the central Netherlands, the Rhine follows a course imposed by Late Quaternary glaciation, forcing it to cross several tectonic blocks of the Roer Valley Graben system before entering the south-eastern North Sea Basin. Holocene sealevel rise resulted in the formation of a coastal prism (Holocene Rhine-Meuse delta). Across the Peel Boundary Fault-zone (PBF) in the central delta, differences in subsidence between the downstream Roer Valley Graben and its upstream shoulder influenced fluvial deposition. This study examines the sedimentary response upstream and downstream of the PBF and uses that to quantify differential subsidence rates. The local identification and quantification of the subsidence component within deltaic relative base-level rise may serve to determine to what extent coastal prism aggradation and resulting architecture are controlled by downstream sea-level rise, local tectonics and discharge coming from upstream.

A floodbasin-section shows both syn-depositional and post-depositional tectonic effects in the Late-glacial to Holocene (marine oxygen isotope stages 2 and 1) sedimentary record, and reveals an active fault of the Peel Boundary Fault-zone. Differential subsidence across the PBF is quantified for the Last Glacial Maximum subsurface (averaged rate $c .0 .06 \mathrm{~m} \mathrm{kyr}^{-1}$ over the past $15 \mathrm{kyr}$ ). The offset in Holocene basal peat yields a similar value $\left(0.03-0.07 \mathrm{~m} \mathrm{kyr}^{-1}\right.$, averaged over the past $7 \mathrm{kyr}$ ). Groundwater-level rise in the study area (as reconstructed from series of radiocarbon-dated basal peats) is used to quantify subsidence by comparison with relative sea-level rise at the river mouth. High rates of subsidence between 7000 and $5500 \mathrm{cal}$. yr BP together with syn-depositional sedimentary evidence suggest that the last major activity (palaeo-earthquakes) along this fault occurred in the middle Holocene. The timing of this and earlier fault activity may be related to the deglaciation and sea-level rise history. The results imply that early-middle Holocene deltaic back-filling should not be attributed solely to downstream relative sea-level rise dominating upstream controls, but that local differential subsidence is another independent control. Similar effects of differential subsidence in coastal prism sedimentary architecture can be expected in other coastal prisms.
\end{abstract}



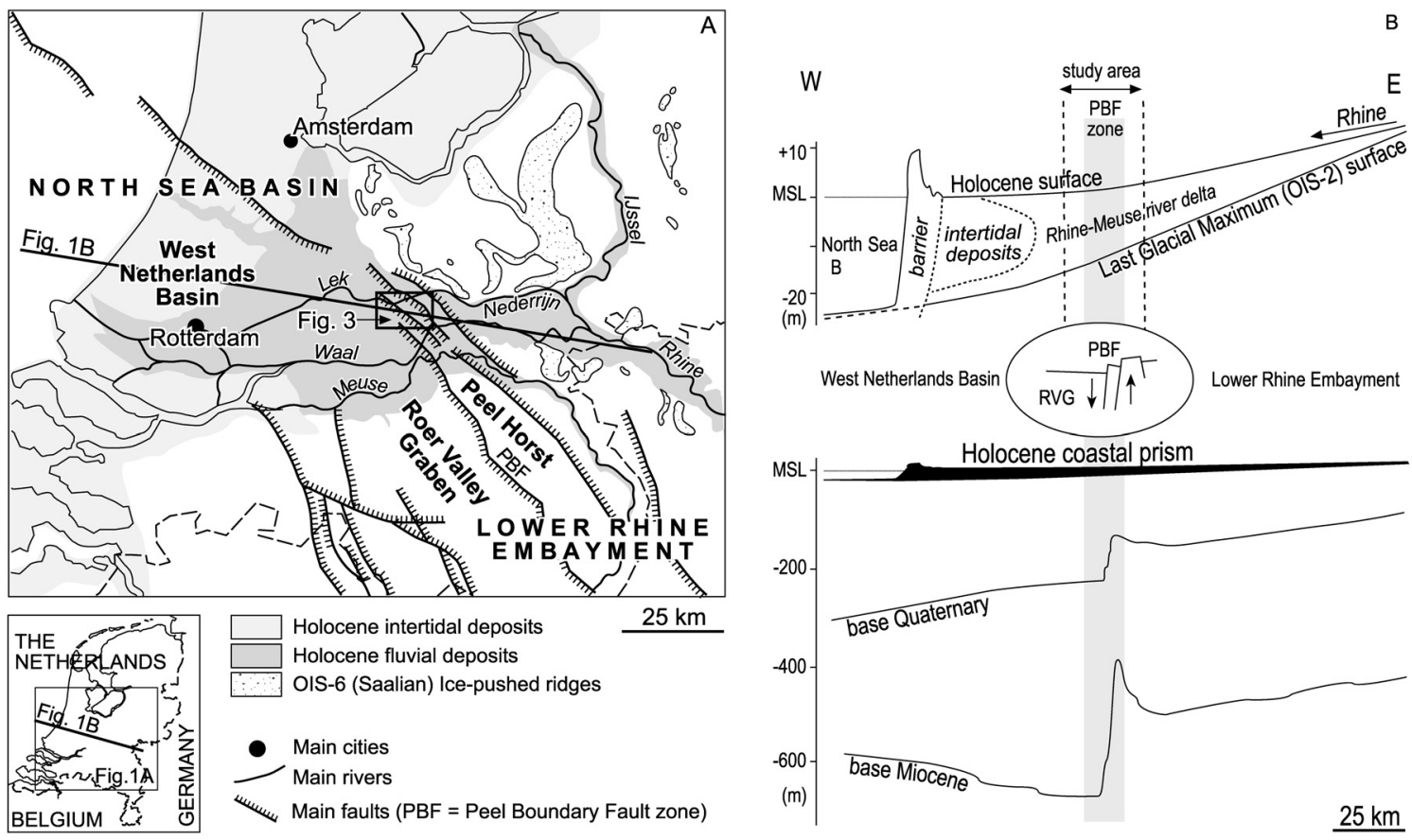

Fig. I Geological setting and Holocene coastal prism and subsurface tectonics. (A) Map of present delta and main neotectonic units. (B) Schematic illustration of subsurface neotectonic structure showing a much generalized crosssection. Base of Quaternary (base Maassluis Formation) after Zagwijn \& Van Staalduinen (1975). Base of Miocene (base Breda Formation) after Zagwijn (1989).

\section{INTRODUCTION}

This study focuses on the response of the River Rhine to differential subsidence across fault zones in the central Netherlands. The study area (Fig. 1) is part of the coastal prism that formed during Holocene sea-level rise towards the present high stand, and covers the active Peel Boundary Fault-zone (PBF). The PBF is related to structural blocks of the Lower Rhine Embayment, an intracontinental rift system that grades into the southern North Sea Basin (West Netherlands Basin, Fig. 1; Geluk et al., 1994). It has a main normal fault that extends from the surface to a depth of $\geq 17 \mathrm{~km}$ (Camelbeeck \& Meghraoui, 1998). Late Quaternary Rhine channels traversed the PBF as they entered the Roer Valley Graben (RVG, the main depo-centre of the Lower Rhine Embayment) from the north-east. South of the Rhine-Meuse delta, the PBF is narrow (less than $1 \mathrm{~km}$ wide) and separates the RVG from the Peel
Block, which forms a topographic high. In the central Rhine-Meuse delta the fault-zone widens and is less well defined. The study area covers the north-western extension of the RVG, PBF and Peel Block (Fig. 1A).

The PBF is of Palaeozoic age, was reactivated in the Tertiary and has been active since (Fig. 1B). Studies showing Late Quaternary and Holocene activity include: seismic monitoring and earthquake hypocentre calculations (Ahorner, 1992), shallow seismographic surveying (Van den Berg et al., 1994), historic seismology (Alexandre, 1994), palaeoseismological studies in trenches and back-stripping of cores (Houtgast \& Van Balen, 2000) and palaeogeographical studies (Van den Berg, 1994; Berendsen \& Stouthamer, 2000; Cohen et al., 2002; Houtgast et al., 2002). Monitoring of seismicity and screening of historic sources has yielded estimates of earthquake activity (maximum local Richter magnitude observed: $5.8 \pm$ 0.1; Roermond, 1992) for the past 100-1000 yr. Palaeoseismological data derived from exposures 
in trenches dug over topographic fault-scarps (Camelbeeck \& Meghraoui, 1998; Vanneste et al., 1999; Lehmann et al., 2001; Van den Berg et al., 2002) cover a wider temporal range (along the RVG typically up to $200 \mathrm{kyr}$ ). Such studies generally have been conducted outside the Rhine-Meuse delta, in the RVG and upstream along the Meuse valley (Fig. 1). The delta itself is unsuitable for trenching because the groundwater table is near the surface. Moreover, the exact locations of faults with Holocene offsets are unknown. However, the Late-glacial to Holocene fluvial record in the study area is continuous, and covers the north-western extensions of the PBF (Cohen et al., 2002). This setting offers opportunities to quantify tectonic deformation and fill the gap between studies based on seismic monitoring and palaeoseismological interpretations of trenched Quaternary sediments, while exploring the fluvio-deltaic sedimentary response to differential subsidence.

\section{Site selection: Holocene floodbasins}

Although low-gradient channel belts preserved in the Rhine-Meuse delta indicate neotectonic activity (deformation in longitudinal profiles, asymmetric meander belts, distribution of avulsion sites; see Verbraeck, 1990; Berendsen \& Stouthamer, 2000; Stouthamer \& Berendsen, 2000; Stouthamer, 2001), it is hard to accurately quantify post-depositional vertical deformation from channel belt deposits. Quantification of aggradation rates by Törnqvist et al. (1998) and timing of the upstream migration of back-filling by Berendsen \& Stouthamer $(2000,2001)$ demonstrated that differential subsidence is recorded in the floodbasins. In contrast to channel belts, fluvio-deltaic floodbasins are stable sedimentary environments: variation in surface elevation occurs over larger distances and the record is essentially continuous. Therefore, floodbasins are a more suitable environment to offer proxies for quantifying vertical neotectonics than channel belts, and hence this study focuses on the floodbasin sedimentary record.

Rising sea level is the primary control on aggradation rates within the floodbasins: the main body of the Rhine-Meuse coastal prism was deposited during middle Holocene back-filling in direct response to the rising sea level (Van Dijk et al., 1991; Törnqvist, 1993). During this sea-level rise, accommodation exceeded sedimentation: floodbasin peat could form extensively because of the relative absence of sediment. Curves of groundwater-level rise quantify aggradation at distal floodbasin locations. Accurately quantifying aggradation rates in floodbasins is possible only where compaction is near zero and hence can be neglected. Such sites (i.e. peat-covered flanks of buried aeolian dunes, Jelgersma, 1961; Van de Plassche, 1982; Van Dijk et al., 1991; Törnqvist et al., 1998) are available, so the compaction problem can be avoided. In the inland parts of the delta, upstream controls (discharge of water and sediment) interplay with the downstream controls, as is shown by the longitudinal gradient of isochrons within floodbasin peat (Van Dijk et al., 1991; Blum \& Törnqvist, 2000, fig. 24). Towards the late Holocene, the rate of sea-level rise decreased. This is reflected by changes in fluvial style and increased clastic floodbasin sedimentation (Törnqvist, 1993; Berendsen \& Stouthamer, 2001) and points to upstream controls becoming more significant and influencing sedimentation further downstream.

Neotectonic activity causing locally higher subsidence rates is a secondary control in this delta. Reach-to-reach variation in sedimentary response to local subsidence conditions can be identified separately from general response to upstream (discharge change) and downstream (relative baselevel rise) controls, which have an impact over the whole delta. Local tectonic controls (Fig. 2) can lead to anomalies in subsurface elevation, sedimentary facies and aggradation rates in a longitudinal direction, which cannot be attributed to the primary controls. Post-depositional tectonic displacement can be quantified from deformed surfaces (Fig. 2A). Tectonic effects in the floodbasin sedimentary architecture, recorded, for example, by the changing distribution of organics and clastics within the sequence (Fig. 2B), are useful when tracing faults, but these are not suitable to quantify tectonic activity. Diverging curves of groundwater-level rise (Fig. 2C) quantify differential subsidence (i.e. relative movement between tectonic blocks). For two nearby sites absolute rise of groundwater levels is equal, whereas subsidence may differ significantly. 


\section{Type of control}

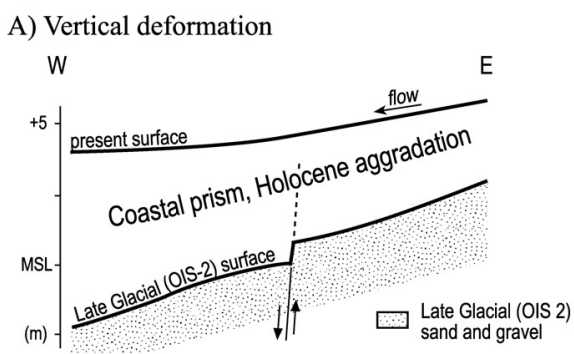

B) Longitudinal architecture

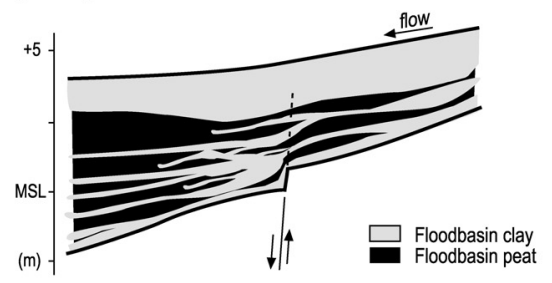

C) Regional groundwater-level rise

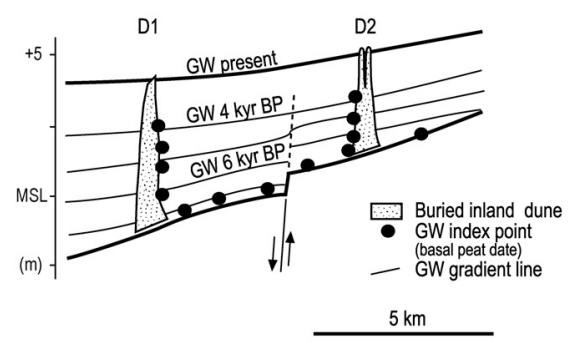

syn-depositional

graded slope

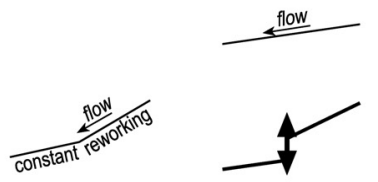

displacement post-depositional

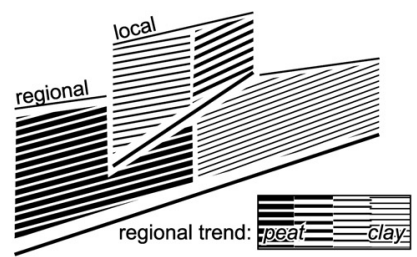

accommodation

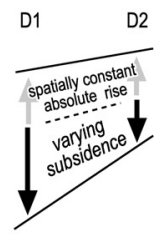

relative rise, aggradation rates

Depth

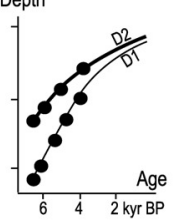

Fig. 2 Means by which postdepositional and syn-depositional controls can be identified.

(A) Differential subsidence affects the graded slope of the river during deposition and causes local offsets at faults after deposition. (B) Differential subsidence affects the sedimentary architecture, causing local deviations from the general longitudinal trend in coastalprism sedimentary architecture. (C) Differential subsidence affects accommodation. Buried dune sites allow the quantification of floodbasin aggradation rates, using age-depth relations of basal peat dates as a proxy for the rising groundwater (GW) level (Jelgersma, 1961; Van de Plassche, 1982;

Van Dijk et al., 1991). Differential subsidence makes groundwater-rise curves diverge back in time.

\section{Aims and approach}

As fault-activity and fluvial deposition in the Rhine-Meuse delta occurred simultaneously during the Late-glacial and Holocene, a sedimentary response reflecting tectonic-alluvial interplay can be expected in the shallow subsurface. For the central Rhine-Meuse delta, indications for Holocene tectonics have been reported by Törnqvist et al. (1998), focusing on aggradation rates, and by Berendsen \& Stouthamer (2000), Stouthamer \& Berendsen (2000) and Stouthamer (2001), focusing on avulsion history. This study aims to identify the sedimentary response upstream and downstream of the PBF, and use it to quantify differences in rates of subsidence. Specific aims of this study are to:

1 trace active faults of the PBF within Holocene coastal prism and the Late-glacial subsurface (to recognize sedimentary features related to differential subsidence, a solid framework for the sedimentary architecture of the study area is needed and a database of over 200000 borehole descriptions and $1250{ }^{14} \mathrm{C}$ ages is available);

2 quantify differential subsidence over time and space and constrain the timing of activity in relation to the fluvial response, and discuss if displacements are related to gradual tectonic creep or to episodic events (displacement related to earthquakes);

3 discuss interplay between local tectonic control and downstream and upstream controls, as well as its implications for coastal prism aggradation.

\section{GEOLOGY OF THE STUDY AREA}

Through most of the Quaternary, the Rhine valley in The Netherlands was oriented SE-NW, 
following the structural trend. Since the Saalian glaciation (marine oxygen isotope stage (OIS) 6), however, the Rhine has essentially followed an E-W course, bordered to the north by relict icepushed ridges (Fig. 1). Thus, the river followed a glacially imposed course, oblique to the structural trend, forcing it to cross relatively stable blocks before entering the Roer Valley Graben in the study area (Cohen et al., 2002). An alluvial valley formed during OIS 4-2 (Törnqvist et al., 2000; Wallinga, 2001) as sea level had dropped considerably, exposing the North Sea floor and extending the Rhine river several hundreds of kilometres (Gibbard, 1995). In the Late-glacial (OIS 2-1 transition) rivers incised in response to climatic amelioration. In the middle Holocene this was followed by back-filling and the formation of a coastal prism, creating well-preserved and datable deposits for each subsequent stage in the delta evolution (Figs 3 \& 4).

In the study area, middle to late Holocene deposits fill the Late-glacial palaeovalley and reach a thickness of $4 \mathrm{~m}$ in the east and $8 \mathrm{~m}$ in the west. The present surface has a gentle westward slope (c. $0.10 \mathrm{~m} \mathrm{~km}^{-1}$ ) compared with the steeper Late-glacial (OIS 2) subsurface (c. $0.30 \mathrm{~m} \mathrm{~km}^{-1}$ ). Upstream of the study area, the coastal prism thins. Downstream of the study area, the valley-fill thickens and spreads over older deposits to the north and south, reaching a width of over $40 \mathrm{~km}$ (Fig. 1).

\section{Sedimentary architecture of the coastal prism}

The coastal prism in the study area (Fig. 3) consists of fine floodbasin deposits (intercalated beds of clay, silty clay, humic clay and peat) that are intersected by sandy channel belts and associated smaller channels (including some crevasse channels). Widespread peats and clayey peats occur in the central ('distal') parts of middle Holocene floodbasins, representing times when regional groundwater rise outran clastic deposition. Local intercalated clayey beds occur within these generally peaty floodbasins, which can be traced laterally to channel belt deposits (levee and crevasse-channel facies). At the base of the Holocene sequence a clayey peat is found. Its presence indicates the onset of aggradation, as the basal peat formed when groundwater levels rose above the valley surface. Basal-peat dates from the study area range between 7200 and 6800 cal. yr BP. Isolated patches of older basal peat are also found (i.e. a strongly humic clay conventionally dated at 8500 cal. yr BP; Hofstede et al., 1989). These patches represent wet environments in small lows on the early Holocene floodplains, inherited from the underlying surface morphology. Floodbasin peat post-dating $4000 \mathrm{cal}$. yr BP is rare in this part of the Rhine-Meuse delta.

The Holocene record can be subdivided into two major units: a clay-dominated upper unit of late Holocene age; and a 2-4 m thick, clay-peat interbedded lower unit of middle Holocene age (Fig. 4, unit B). A stacked system of channel belts is embedded in the middle Holocene floodbasin deposits (Fig. 4, unit A), which by c. 5.3 cal. yr BP was fully abandoned. Its deposits were covered by widespread peat, while the main Rhine discharge was routed north of the study area (see Berendsen \& Stouthamer, 2001). Deposition of the upper $2 \mathrm{~m}$ of floodbasin clay (Fig. 4) started c. 4.9 cal. yr BP, and coincided with late Holocene decreased aggradation rates. The abundant upper Holocene clay is attributed to changes in sediment discharge caused by both climatic change and human deforestation in the Rhine drainage basin and frequent nearby avulsions (Stouthamer \& Berendsen, 2000), which brought a series of distributary channels into existence in the area (Fig. 4, unit C). The present 'Lek' and 'Linge' channels (Fig. 3) are the human-controlled end-members of these late Holocene channels.

\section{Late-glacial (OIS 2, Late Weichselian) subsurface}

Reconstruction of the Late Weichselian surface (OIS 2, Figs 3 \& 4) is based primarily on archived lithological borehole descriptions. Various criteria were applied, discriminating a Last Glacial Maximum (LGM, OIS 2) terrace and incised Lateglacial and early Holocene (OIS 2-1 transition) channel belts. These include geometrical and lithostratigraphical relationships as well as sedimentary and pedogenetic features. The main criteria were: the relative elevation of the top of channel deposits; the lithology of these deposits; the presence, relative elevation, thickness, lithology and structure of the floodplain loam covering the channel deposits (Wijchen Member, 


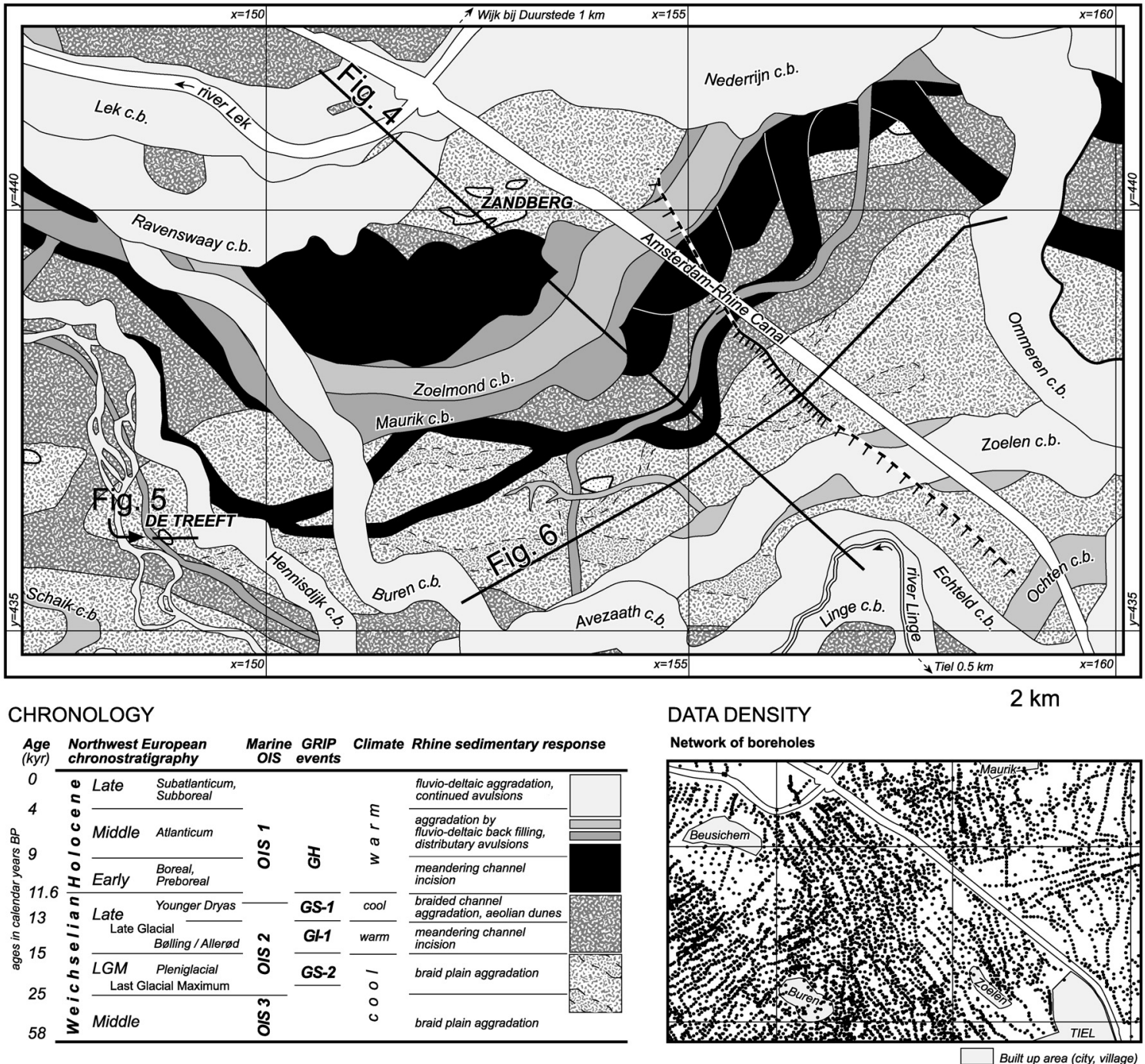

\section{LEGEND}

Fluvial channel deposits, Holocene (OIS-1)

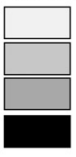
Late Holocene channel belt ( $5 \mathrm{kyr}$ cal BP and younger)
Middle Holocene channel belt ( $6 \mathrm{kyr}-5 \mathrm{kyr}$ cal BP)
Middle Holocene channel belt ( $7 \mathrm{kyr}-6 \mathrm{kyr}$ cal BP)
Early-Middle Holocene channel belt (prior to $7 \mathrm{kyr}$ cal BP

Fluvial channel deposits, Weichselian (OIS-2)

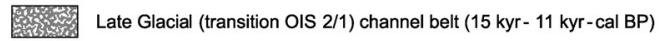
Fis Other features

Late Glacial (transition OIS-2/1) aeolian dune (12 kyr -11 kyr cal BP)
Subsurface fault scarp in Late Glacial and Holocene deposits

Fig. 3 Geological map and stratigraphy of the study area. The figure integrates new mapping of the Late-glacial, early and middle Holocene channel deposits at the base of the coastal prism with previous mapping of middle and late Holocene systems by Verbraeck (1984), Hofstede et al. (1989), Makaske (1998) and Stouthamer (2001). Names of channel belts are taken from Berendsen \& Stouthamer (2001). A correlation of north-west European terrestrial chronostratigraphy with marine (SPECMAP, Martinson et al., 1987) and Greenland ice-core (following Walker et al., 1999) oxygen isotope stages is provided. 


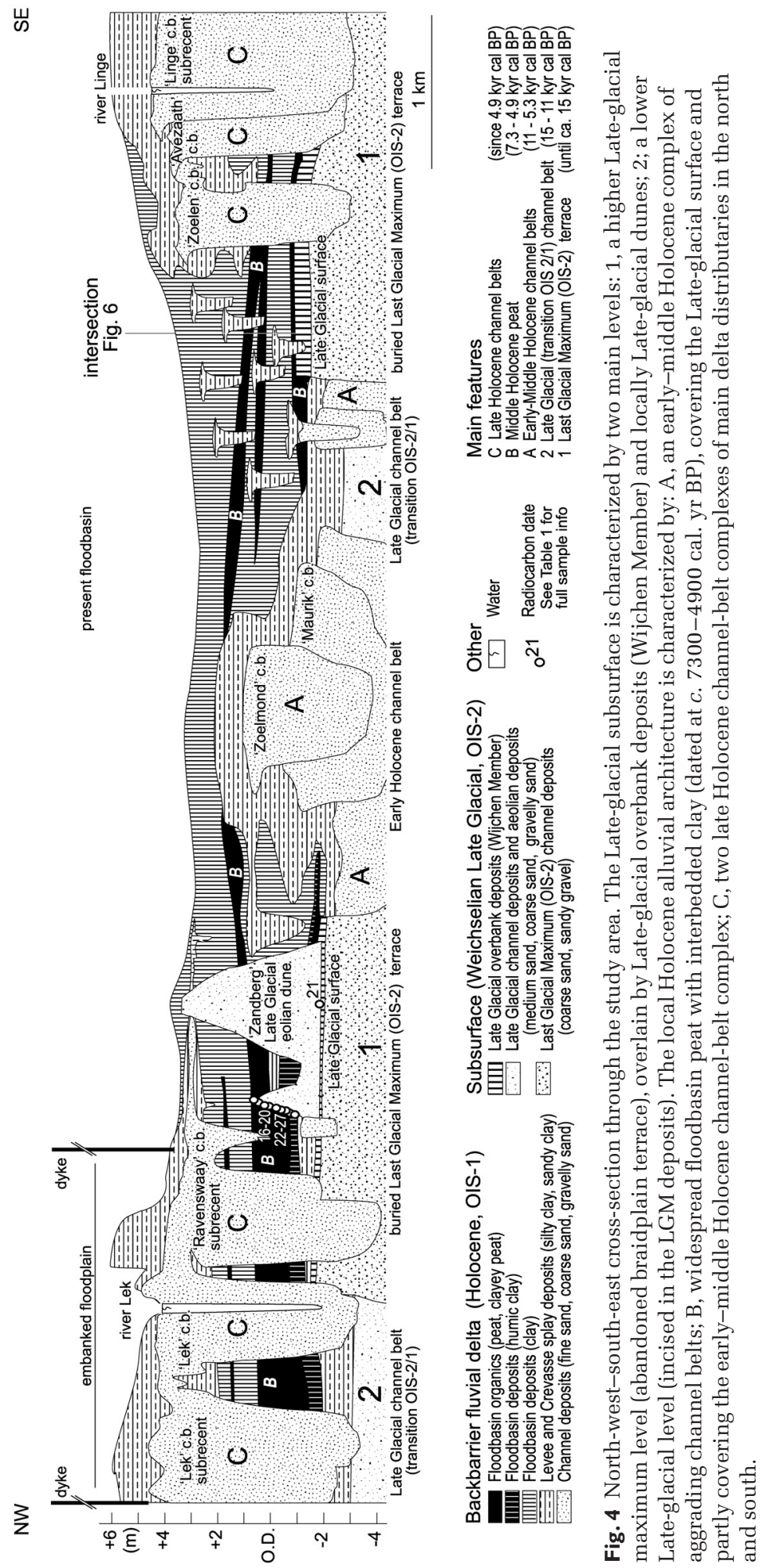


see below); the spatial distribution and thickness of the oldest floodbasin clay beds and longitudinal continuity of channel belts (see Cohen et al., 2002). The highest parts of the subsurface (Fig. 4, unit 1) form a terrace dating to the LGM (OIS 2). Incised channel belts date to the OIS 2-1 transition (Fig. 4, unit 2) and have surfaces at c. $1.5 \mathrm{~m}$ below the LGM terrace (Fig. 4). The Wijchen Member (Törnqvist et al., 1994), forming the top of the LGM terrace, is a clay-loam with admixed coarse sand $c .0 .50 \mathrm{~m}$ thick. This deposit is an important stratigraphical marker in the RhineMeuse delta, and represents floodplain deposition during the OIS 2-1 transition, prior to the onset of Holocene aggradation. Scattered over the study area, isolated inland dunes of Late-glacial age (Kasse, 1995; Berendsen \& Stouthamer, 2001) occur on top of the LGM terrace, along the younger incised channel belts. The Late-glacial surface is similar to upstream areas, where the OIS 2 terrace geomorphology is still preserved (Berendsen et al., 1995; Huisink, 1997; Tebbens et al., 1999, 2000). The reconstruction further suggests that early Holocene meandering channels reworked the preceding OIS 2-1 channel belt and at some locations laterally cut into the superelevated OIS 2 terrace, similar to early and middle Holocene meander scars found upstream along the Rhine near the Dutch-German border (Klostermann, 1992; Berendsen \& Stouthamer, 2001).

\section{METHODS}

Field activities in the summer of 1999 and 2000 consisted of collecting 70 additional hand cores (auger holes). Using the method described by Berendsen \& Stouthamer (2001), cores were described in the field at fixed intervals of $10 \mathrm{~cm}$. Cores were numbered systematically and the geographical location $( \pm 5 \mathrm{~m}$, Dutch coordinate system) and surface elevation ( $\pm 0.1 \mathrm{~m}$, relative to $\mathrm{OD}=\mathrm{NAP} \approx$ mean sea level) were registered. At locations where radiocarbon samples were taken, surface elevation and sample depth were obtained through levelling, with an accuracy of $\pm 2 \mathrm{~cm}$. Fieldwork concentrated on two sites: (i) at the 'Treeft' buried Late-glacial dune (Figs 3 \& 5), where basal peat samples were collected to reconstruct Holocene aggradation rates; and (ii) along a longitudinal transect (Figs 3 \& 6) in which the effects of neotectonic activity were studied.

\section{Radiocarbon dating groundwater-level index points}

Eleven basal peat samples were collected from cores $30-50 \mathrm{~cm}$ long spanning the transition of the Late-glacial subsurface to Holocene basal peat. The basal peat in the core was cut in slices $1 \mathrm{~cm}$ thick starting $2 \mathrm{~cm}$ above the interface with the underlying substrate, and organic macrofossils were selected using a $150 \mu \mathrm{m}$ sieve. Specific macrofossils, mainly Alnus nuts (following Törnqvist et al., 1998), were radiocarbon dated at the R.J. van der Graaff Laboratory, Utrecht University, using accelerated mass spectrometry (AMS).

The age and depth of 21 basal peat samples (12 samples dated earlier and 9 samples collected for this study) were used as a proxy for groundwater level (Fig. 7). Each basal peat sample directly indicates a palaeogroundwater level. The largest source of uncertainty in this proxy is the tolerance of the dated plant species to variations of the groundwater level. Age and depth errors related to the sampling are of minor importance. Törnqvist et al. (1998) estimated the vertical accuracy of AMS-dated Alnus peat as a proxy for average groundwater levels in the floodbasin at $\pm 10 \mathrm{~cm}$, with a bias towards levels slightly above the sample, because of its preservation as peat. At the 'Treeft' dune site, the difference in elevation of some of the samples is $<30 \mathrm{~cm}$, and the resulting dates do not overlap within a range of one standard deviation. This indicates that a vertical accuracy of $20 \mathrm{~cm}$ for this proxy is a fair estimate, at least for the period of relatively rapid groundwater rise in the middle Holocene. Table 1 presents all the radiocarbon dates used in this paper.

A series of dates from Holocene peat overlying the flanks of isolated inland dunes can be used to reconstruct the rise of groundwater. Age and depth of basal peat dates plot as groundwaterindex points on groundwater-rise curves. This method was first applied to quantify relative sea-level rise from near-coastal sites (Jelgersma, 1961; Van de Plassche, 1982). Later it was used in inland fluvial floodbasins (Van Dijk et al., 1991). The location of the basal peat, directly overlying 


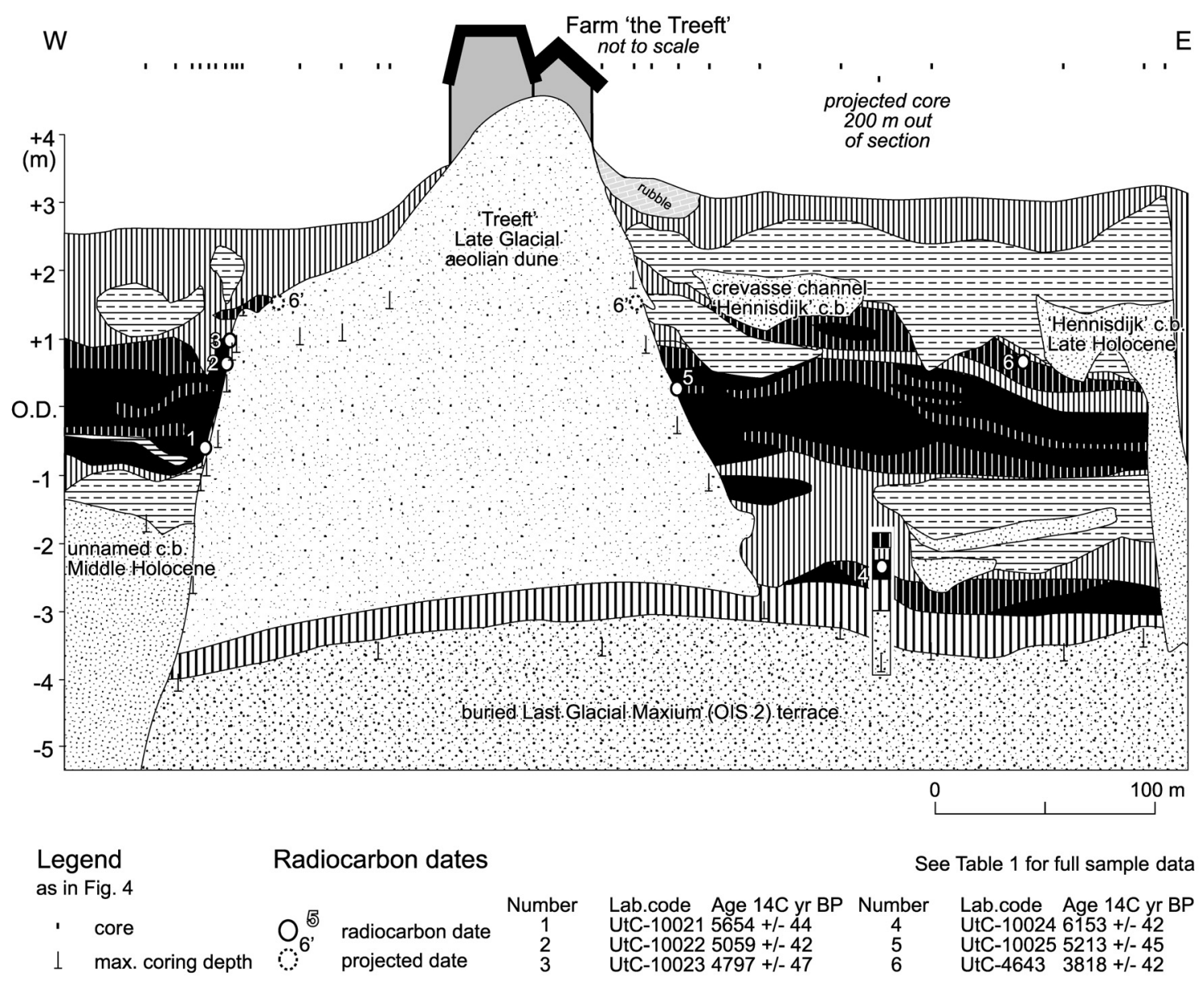

Fig. 5 Cross-section through the 'Treeft' aeolian dune. Holocene peat directly overlying a Late-glacial inland dune was dated at five locations to reconstruct groundwater-level rise. An earlier dated sample (sample 6; Makaske, 1998) was used as an additional (indirect, projected) groundwater-level index point. Ornamentation is the same as in Fig. 4.

dune sand, virtually excludes effects of postdepositional compaction, and the elevation of the basal peat samples directly represents the regional groundwater-table elevation at the time of peat formation. Alternatively, dates from basal peat overlying the LGM terrace may be used as groundwater index points. Prior to the formation of this peat, the terrace surface was superelevated above regional groundwater levels for a considerable period of time. The Wijchen Member loam on top of the LGM terrace represents a period of 3-6 kyr between abandonment (c. 15000 cal. yr BP) and middle Holocene peat formation (c. $7000 \mathrm{cal}$. yr $\mathrm{BP})$. The structure of the Late-glacial loam indicates pedogenesis (i.e. lessivage). The 0.5-m-thick loam is assumed to have compacted to this thickness mainly during stages of active pedogenesis and subaerial exposure, and did not compact after burial. The loam on average has the same thickness all over the Rhine-Meuse delta, whether it is buried by $15 \mathrm{~m}$ of Holocene clay and peat, by $5 \mathrm{~m}$ of Holocene clay, or hardly buried at all and remains partly subaerially exposed (Berendsen \& Stouthamer, 2001). Hence, compaction of the loam after peat formation can be neglected, and basal peat samples from this type of location can be used as groundwater indicators, similar to basal peat at dune flanks.

Groundwater levels prior to the onset of aggradation cannot be reconstructed using basal peat 


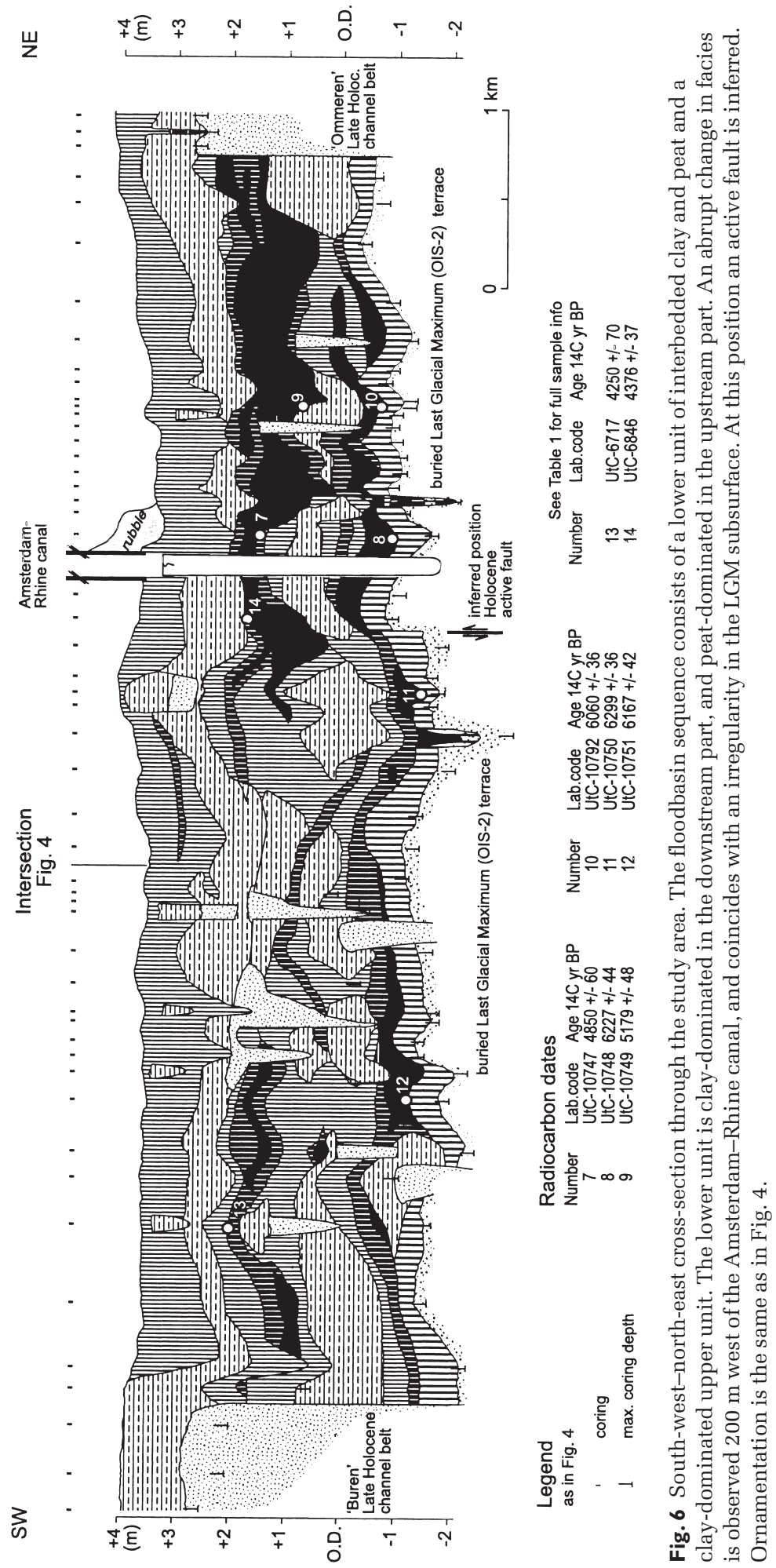




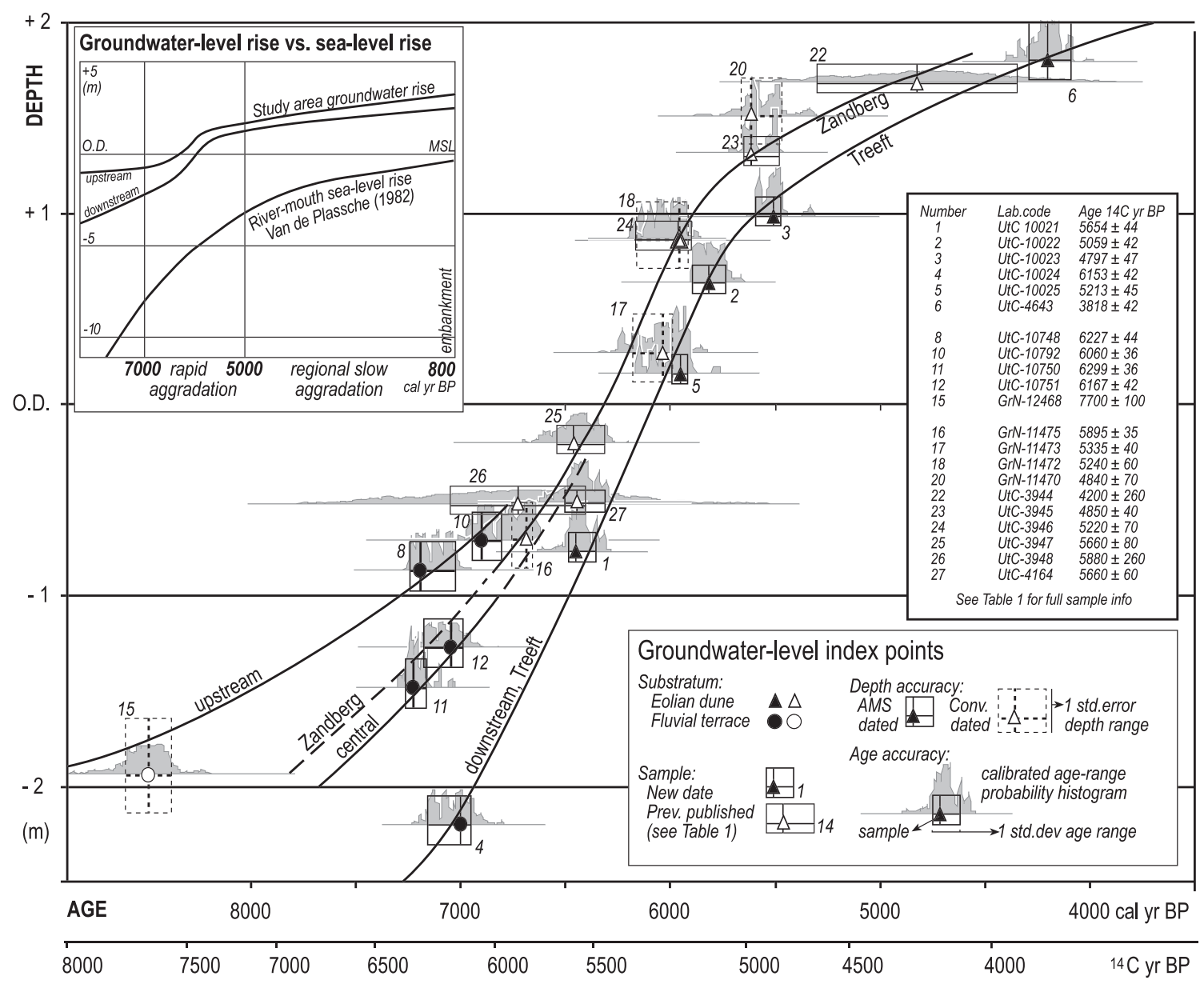

Fig. 7 Age-depth plot of radiocarbon dated basal peats. The age-depth relation for basal peat is a direct proxy for the yearly average palaeogroundwater level in the fluvial floodbasin. Basal peat samples are used as groundwater-index points, with standard deviation error boxes. The width of the error box represents the maximum and minimum of the calibrated calendar age range (Table 1), with the index point plotted at the mean of the largest calibrated-age subrange. Heights of error boxes (following Törnqvist et al., 1998): $0.15 \mathrm{~m}$ for AMS-dated samples in series, $0.25 \mathrm{~m}$ for isolated AMS-dated samples, $0.35 \mathrm{~m}$ for conventionally dated samples in series, $0.50 \mathrm{~m}$ for isolated conventionally dated samples. Of this height, two-thirds is above the index point and one-third is below it, incorporating bias towards palaeogroundwater levels slightly above the preservation depth of the sampled peat. Age-range probability histograms for individual samples were created using the OxCal program (Bronk Ramsey, 1995; version 3.5) and the latest calibration data set (Stuiver et al., 1998).

levels, but some general estimates can be made based on subaerial pedogenetic features in the Wijchen Member, and on the preservation of in-fills of Late-glacial residual channels. The Wijchen Member pedogenetic features point to groundwater levels (before the onset of aggradation) that must have been at least $0.5 \mathrm{~m}$ below the surface for some time. Residual channels filled with Late-glacial and early Holocene peat and gyttja in oxbow lakes have been preserved locally and indicate a minimum early Holocene groundwater level of $0.5-2.0 \mathrm{~m}$ below the LGM terrace surface (Cohen, 2003). Thus, unlike sea level, the groundwater-level was not tens of metres below the present level in the early Holocene, but at most 1-2 $\mathrm{m}$ below the OIS 2-1 valley surface, which is consistent with hydrological considerations of groundwater and fluvial discharge (De Vries, 1974). 


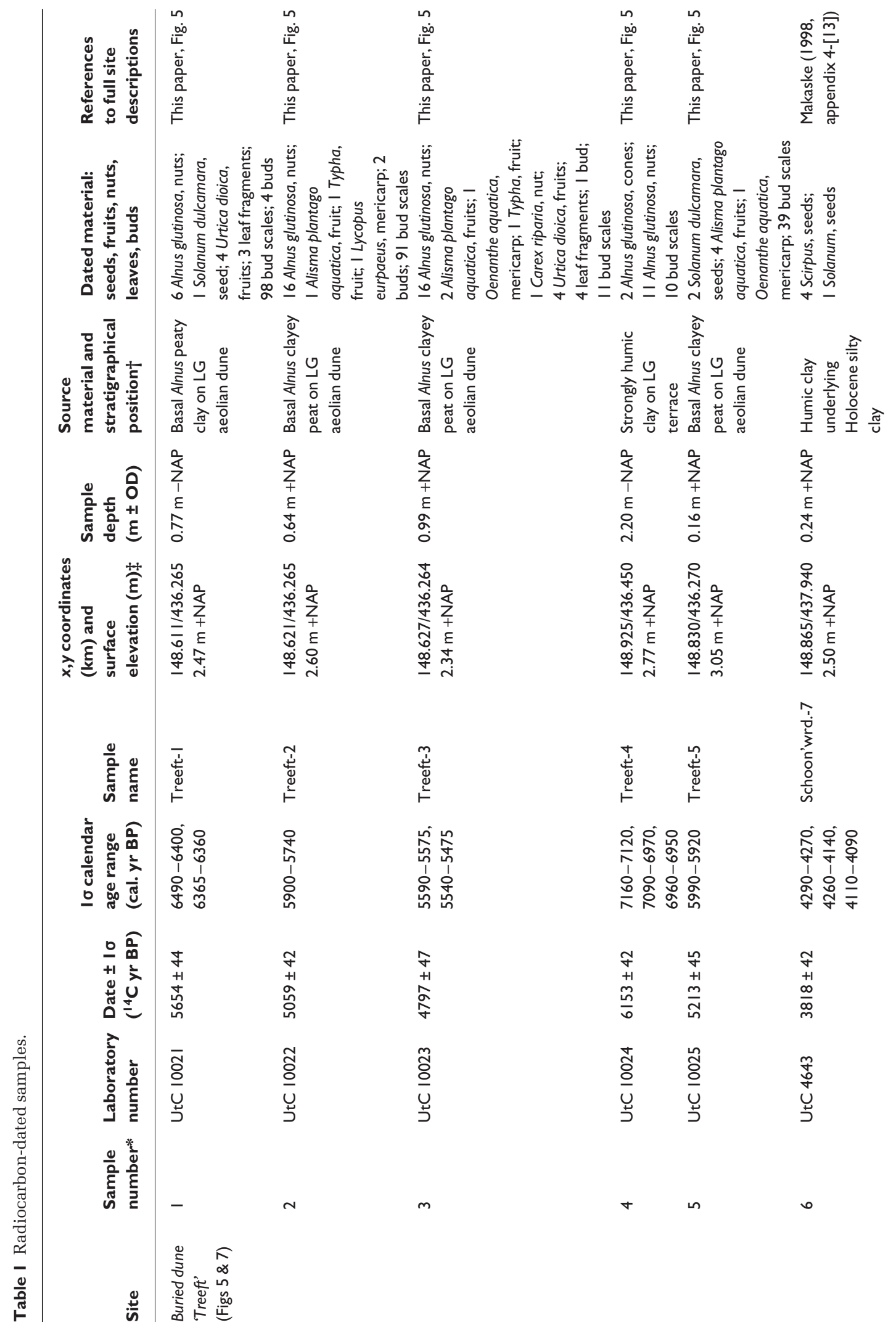




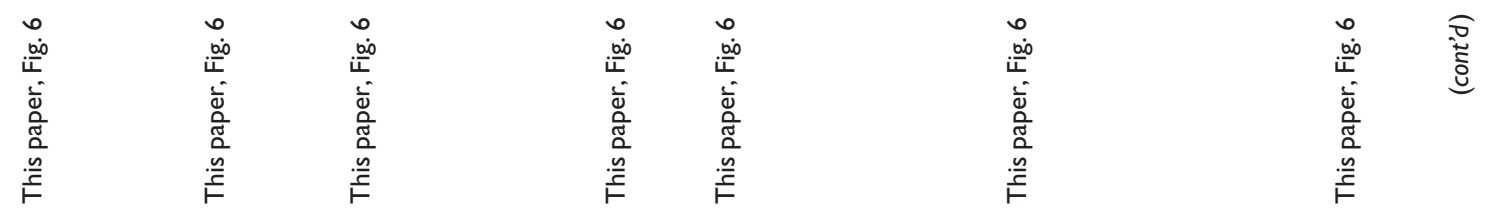
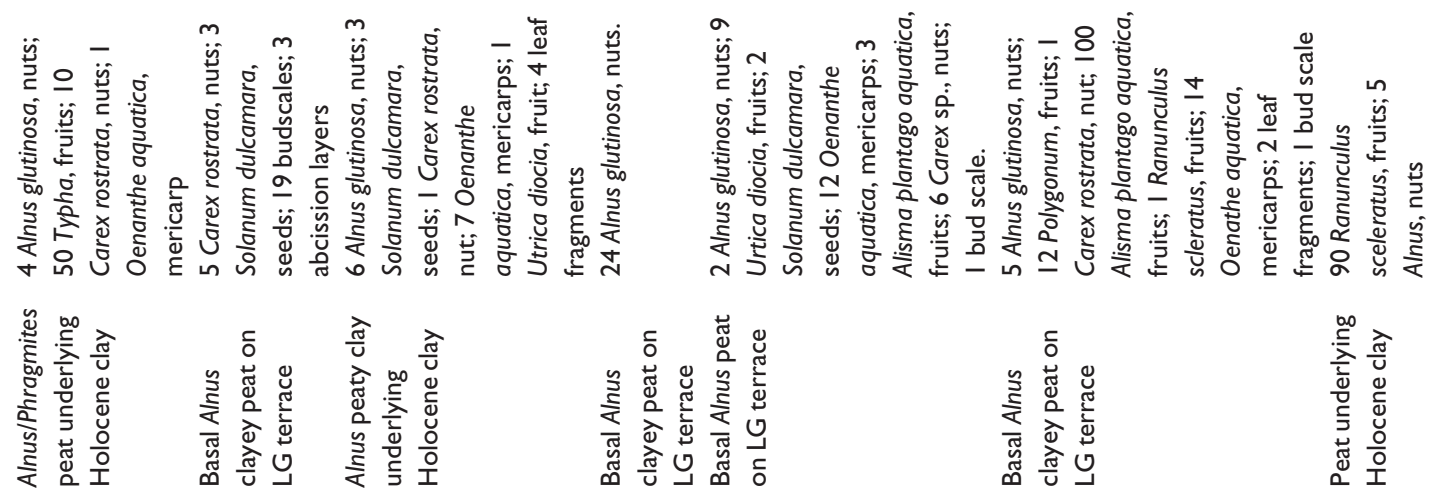

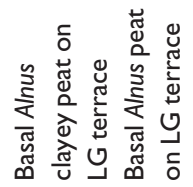

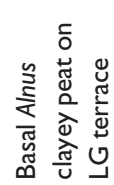

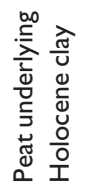

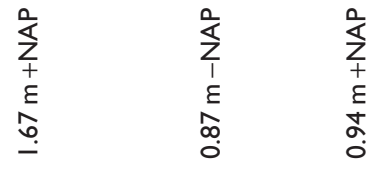

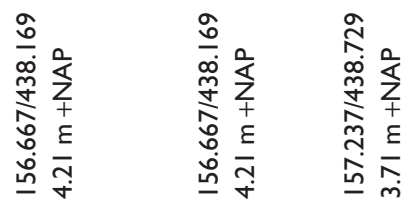

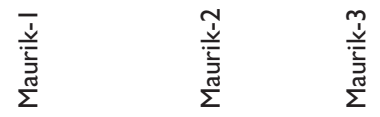

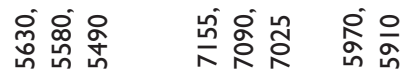

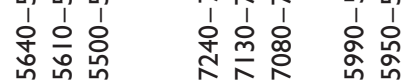

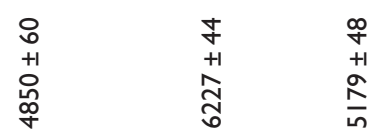

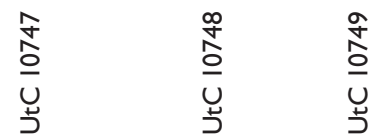

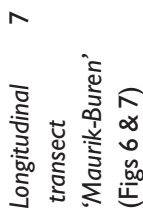

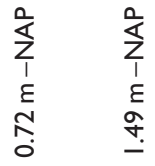

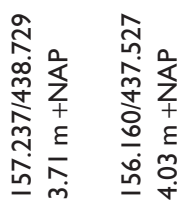

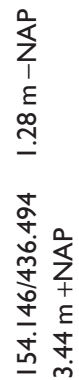

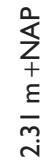

은

紋足

ฮิ

กู่

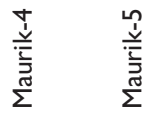

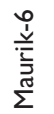

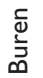

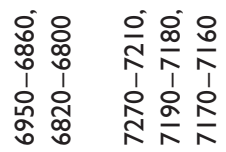

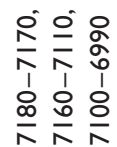

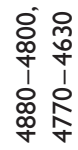

$\begin{array}{ll}0 & 0 \\ m & m \\ +1 & +1 \\ 0 & 0 \\ 0 & 0 \\ 0 & 0\end{array}$

$\frac{6}{4}$
$\frac{1}{+1}$

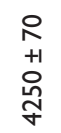

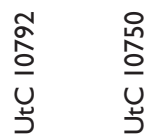

商

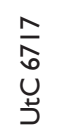

으 =

I

$\underline{m}$ 


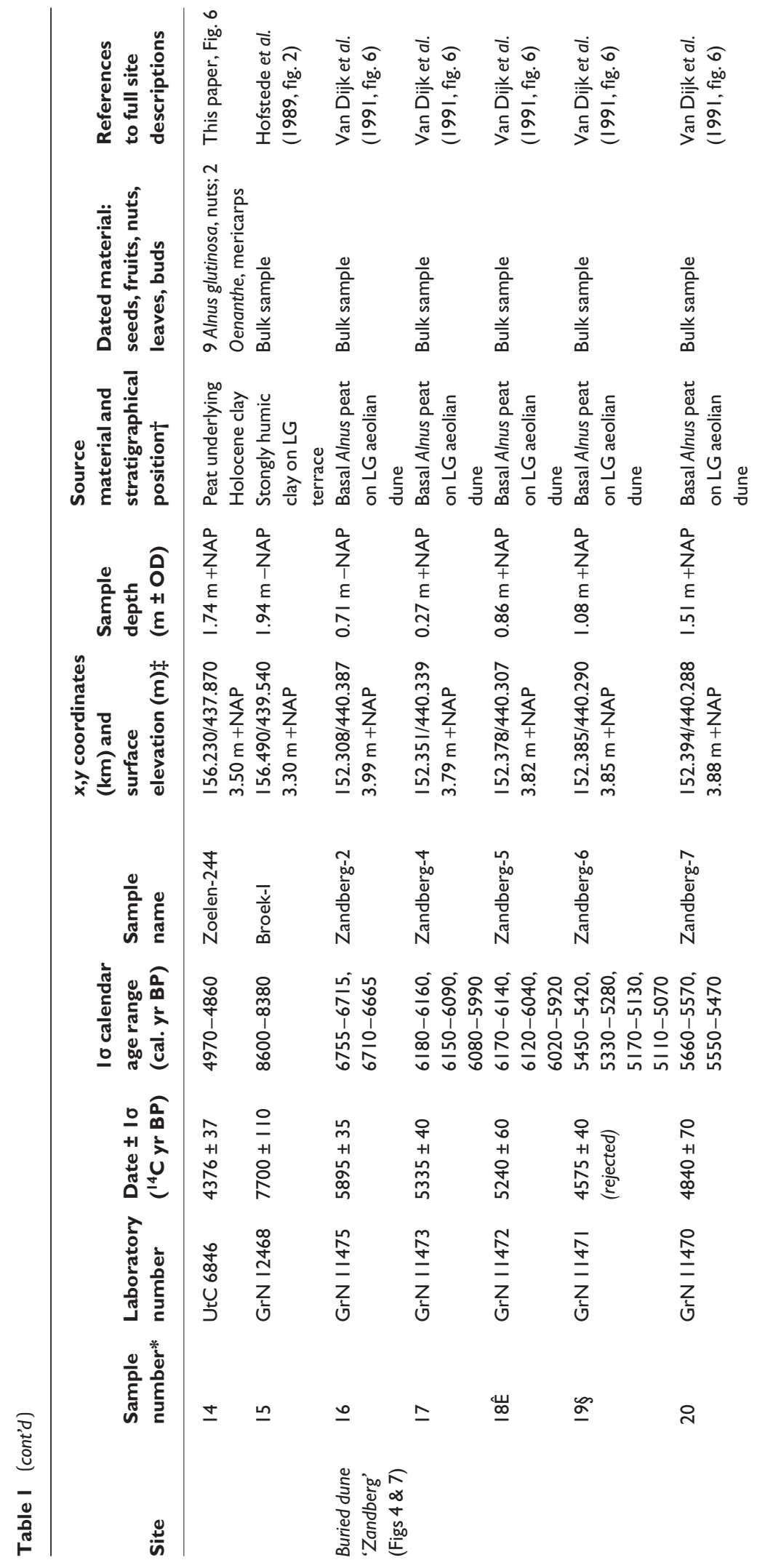




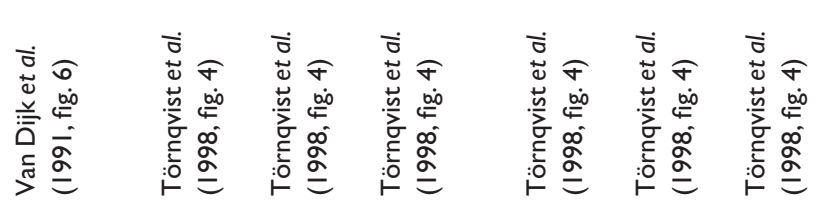

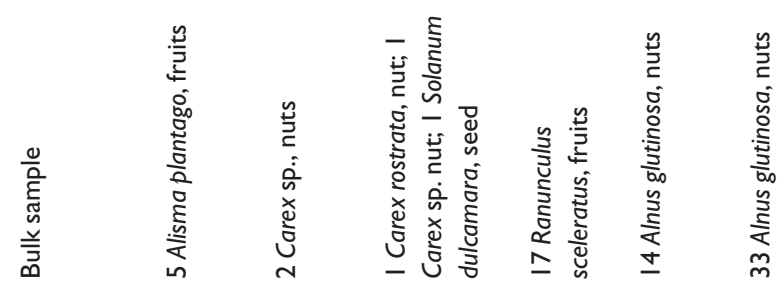

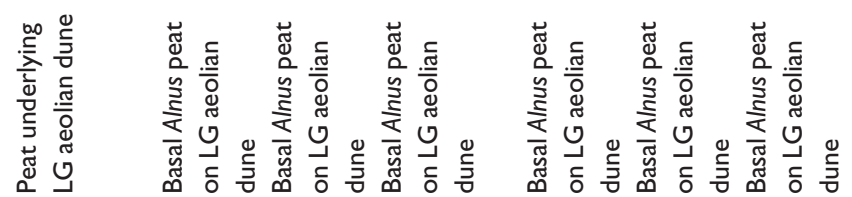

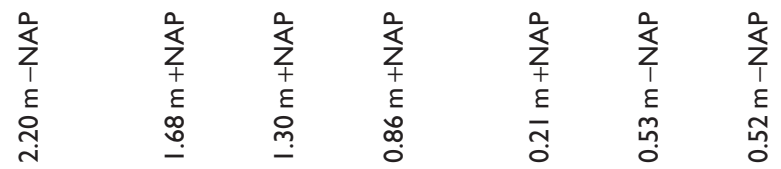

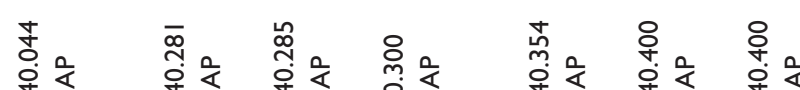

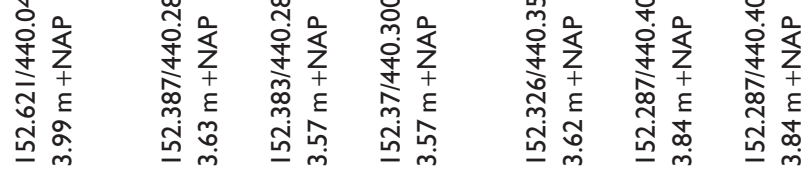

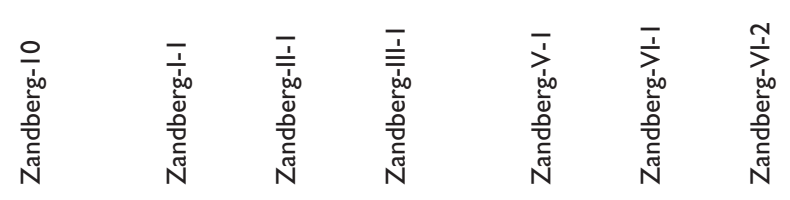

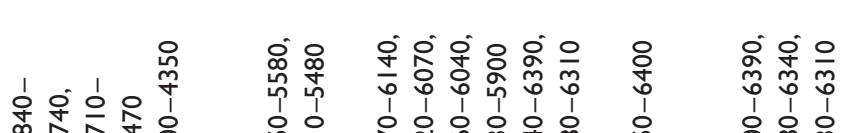

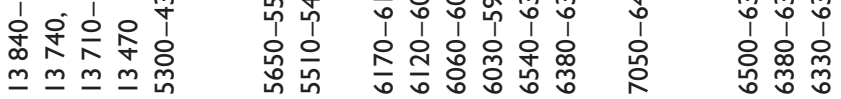

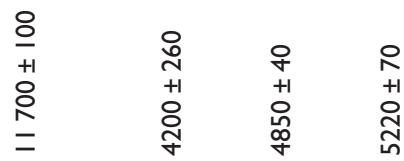

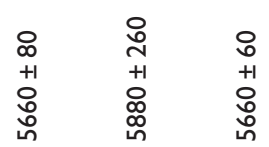

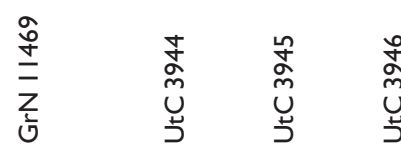

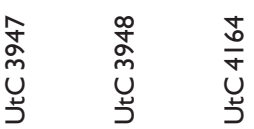

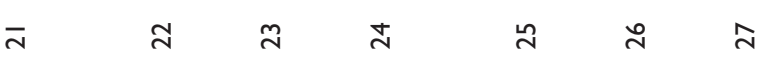

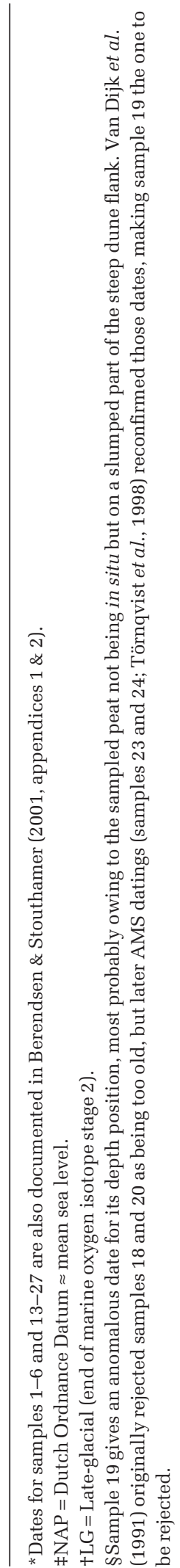




\section{SITE DESCRIPTIONS}

For the 'Zandberg' inland dune, located centrally in the study area, a series of samples was available (Table 1; Van Dijk et al., 1991; Törnqvist et al., 1998). More basal peat samples were collected in its vicinity, as well as from new sites to expand the age-depth range and to increase the spatial coverage and temporal resolution of the reconstructed aggradation rates.

\section{'Treeft' buried dune site}

Five basal peat samples were collected from the flanks of the 'Treeft' buried aeolian dune (Fig. 5) in the western part of the study area (Fig. 3). All samples were used as groundwater-index points. Samples 1, 2 and 3 (Table 1) from the western flank and sample 5 from the eastern flank were taken from a clayey peat layer on-lapping the dune between -0.5 and $+1.0 \mathrm{~m}$. The presence of a palaeosol directly beneath these samples suggests an undisturbed contact between peat and a palaeosurface. Disturbed basal-peat contacts (i.e. resulting from slumps along steep dune flanks) were avoided because macrofossils at such locations are not in situ and thus do not represent the groundwater level. Sampling from local depressions was avoided by drilling cores at distances of less than $5 \mathrm{~m}$. Local depressions have to be avoided, because peat formation here may have started earlier (Van de Plassche, 1982; Törnqvist et al., 1998). Sample 4 (Table 1; Fig. $5 ;-2.20$ m), at the lowest elevation, dates basal peat that formed at a relatively high elevation on the Late-glacial surface.

At the 'Treeft' site, the transition (at +1 m OD) between the peat-clay intercalated lower unit and the clayey upper unit marks the beginning of activity of the nearby 'Hennisdijk' channel belt (Fig. 3), which has been dated by various authors (Verbraeck, 1984; Makaske, 1998). Sample 6 (Table 1; Makaske, 1998) is from a humic clay layer that can be traced across the section. At the western flank it intersects the dune at $+1.5 \mathrm{~m} \mathrm{OD}$, indicating a groundwater level at that stratigraphical position just before the 'Hennisdijk' channel formed. As this elevation is derived indirectly from laterally tracking a lithological transition, this index point is less accurate than data provided by directly dated basal peat samples.

\section{Longitudinal section}

To trace the PBF within the Holocene sediments and Late-glacial subsurface, a longitudinal section $7 \mathrm{~km}$ long was cored, at a location chosen using the data available (Fig. 3). The section aimed: (i) to traverse mainly distal floodbasin deposits, as far away as possible from Holocene channels; (ii) to cover a relatively old patch of the Late-glacial subsurface; (iii) to cover a large distance both upstream and downstream from the approximate position of the PBF. The section is located parallel to the present 'Lek' and 'Linge' channels (Fig. 3), and terminates at the subrecent 'Ommeren' and 'Buren' channel belts (Figs 3 \& 6). It was constructed using new cores and additional selected cores from the database. In four cores, clayey basal peat was sampled to obtain radiocarbon dates for the onset of aggradation along the section (sample 8, 10, 11 and 12; Table 1). Four additional peat samples were used to further date the floodbasin sequence (samples 7, 9, 13 and 14; Table 1).

Within the section, several smaller channel belts and crevasse channels of middle Holocene age are recognized that have coexisted with the 'Maurik' and 'Zoelmond' (Fig. 3) channel belts, and some late Holocene crevasse channels were also recognized. The main part of the section consists of floodbasin deposits, with the previously described middle Holocene clay-peat intercalated lower unit ( -1 to $+2 \mathrm{~m}$ ) and late Holocene clay-dominated upper unit $(>2 \mathrm{~m})$. Following the radiocarbon dates (Table 1) the middle Holocene unit formed between $7200 \mathrm{cal}$. yr BP and $4900 \mathrm{cal}$. yr BP, covering the period of highest Holocene aggradation rates in this area.

\section{RESULTS}

\section{Fault displacement in the longitudinal section}

To find the Late-glacial and Holocene active faults of the PBF zone, longitudinal changes in sedimentary facies and vertical deformation of isochron surfaces were sought within the coastal prism (see Fig. 2). Three indications for neotectonic activity were found in the longitudinal section (Fig. 6).

1 East of the Amsterdam-Rhine canal, the lower floodbasin unit consists predominantly of peat, 
whereas to the west clay beds are intercalated in the peat (Fig. 6). This is in contrast to the general trend in the Rhine-Meuse delta, which is a downstream decrease in clastics and an increase in peat (Törnqvist, 1993; Berendsen \& Stouthamer, 2001). The floodbasin clays intercalated in the peat are the distal ends of the crevasse splays of crevasse channels that are also recognized in the lower floodbasin unit. Alternative ways of sediment delivery, such as discharge overtopping the levee instead of breaching it, will have contributed sediment too, but the number of crevasse channels and the lateral grading into distal clayey splays and floodbasin clayey peat point to splay formation as the most important contributor. The local, abrupt change of facies seems to be related to differences in aggradation rates in the upstream and downstream part of the section: clastic sediment entering the floodbasin from the surrounding channels was preferentially deposited in the most subsiding area (similar to Fig. 2B). This does not necessarily imply that fault activity caused breaching and created crevasse splays, but apparently splays developed preferentially in the more subsiding area.

2 Middle Holocene aggradation over the lower parts of the LGM (OIS 2) terrace surface started around $7200 \mathrm{cal}$. yr BP (samples 8 and 11, Table 1) and some $100 \mathrm{yr}$ later covered the higher parts of the surface (samples 10 and 12). The four basal peat samples in the section thus all yielded similar ages (7200-6900 cal. yr BP, Table 1), but the downstream samples (11 and 12) and upstream samples (8 and 10) differ by c. $0.60 \mathrm{~m}$ in elevation (Fig. 6). This elevation difference occurs over a short distance $(2 \mathrm{~km}$ between the mean coordinates of both sample pairs) and the apparent gradient in the $7100 \mathrm{cal}$. yr BP groundwater level is high $\left(0.3 \mathrm{~m} \mathrm{~km}^{-1}\right)$ compared with later Holocene gradients $\left(0.1-0.2 \mathrm{~m} \mathrm{~km}^{-1}\right.$, Van Dijk et al., 1991). The lateral continuity of the basal peat and its macrofossil composition suggest that the palaeogroundwater level was fluvially controlled and had a gradient that changed only very gradually over space. It is therefore concluded that the present $c .0 .60 \mathrm{~m}$ basal peat elevation difference is anomalous: after the peat formed, downstream samples must have subsided relative to upstream samples (post-depositional deformation, as in Fig. 2A). Not all of the $c .0 .60 \mathrm{~m}$ sampleoffset can be attributed to vertical deformation; corrections need to be made (see below).
3 One of the major irregularities in the buried LGM (OIS 2) terrace coincides with the longitudinal facies change in the overlying Holocene sequence and the palaeogroundwater age-depth anomaly at the onset of aggradation. The top of the Late-glacial surface was mapped in a zone $4 \mathrm{~km}$ wide along the section. The offset could be traced for about $2 \mathrm{~km}$ perpendicular to the transect of Fig. 6 and was found to cross-cut the LGM (OIS 2) terrace as well as the Late-glacial (OIS 2-1) channel belt (Fig. 3). The upstream side is about $0.7-1.0 \mathrm{~m}$ higher than the downstream side. The NW-SE direction matches the strike of the faults known from the deeper subsurface (Van Montfrans, 1975). It is concluded that the irregularity marks one of the faults of the PBF that was active during the past $15 \mathrm{kyr}$, dividing the section into an upstream reach that was relatively elevated and a downstream reach that was relatively subsiding (similar to Fig. 2A).

The above three phenomena occur at the same location, which, when combined with the known existence of faults at depth, leads to the conclusion that differential subsidence in the study area not only caused post-depositional deformation along the inferred fault, but also was a syn-depositional control over the past 15 kyr.

\section{Reconstructed groundwater-level rise}

Holocene groundwater-level rise reflects increasing accommodation space (Van Dijk et al., 1991; Blum \& Törnqvist, 2000). Curves representing regional (floodbasin) groundwater-level rise are presented in an age-depth graph (Fig. 7). All curves essentially have the same sigmoidal shape, with a rise that increased but remained relatively slow prior to the onset of extensive basal peat formation at $7200 \mathrm{cal}$. yr BP. The most rapid rise occurred after the onset of basal peat formation, and rates decreased after 5500 cal. yr BP. The difference in elevation between individual curves is primarily the effect of the river gradient: like the water-level gradient in the active channels, the groundwater level in the floodbasins between the channels is higher at sites further upstream (Van de Plassche, 1982; Van Dijk et al., 1991). To draw the curves, all dates from the 'Treeft' site (Fig. 5) and from the longitudinal section (Fig. 6) were accepted as correct. The previously published 
dates of the 'Zandberg' site (Van Dijk et al., 1991; Törnqvist et al., 1998) and surrounding area (Hofstede et al., 1989) were all accepted, except one sample that was rejected because it was clearly too young (date 19; Table 1).

The upstream curve covers the 8500-6500 cal. yr BP period, and represents the stage prior to extensive basal peat formation, when peat formation occurred only locally (date 15). The 'Treeft' and 'Zandberg' sites cover the period 75004000 cal. yr BP and show that by c. 7000 cal. yr BP (samples 4, 8 and 10-12) groundwater level had risen above the OIS 2 valley surface. The steep curve between 7000 and $5000 \mathrm{cal}$. yr BP represents the stage of most rapid groundwater-level rise, with widespread peat formation in the distal parts of the floodbasin, and crevasse-splay deposition (see above) downstream of the inferred fault (Fig. 6). After 5700 cal. yr BP rates decreased towards an approximately linear rate of $0.5 \mathrm{~m} \mathrm{kyr}^{-1}$. After $4000 \mathrm{cal}$. kyr BP peat is absent in the floodbasins, hence no basal peat index points are available from this period.

The 'Treeft' site is located $5 \mathrm{~km}$ downstream of the 'Zandberg' site. Groundwater levels at
7000 cal. yr BP differ by c. $1.2 \mathrm{~m}$ between the two sites (Fig. 7), yielding a floodbasin groundwater gradient of $c .0 .2 \mathrm{~m} \mathrm{~km}^{-1}$, approaching the valley gradient of the OIS 2-1 floodplain $\left(0.25-0.30 \mathrm{~m} \mathrm{~km}^{-1}\right)$. At this time, aggradation had just set in and channel belts in the study area were adapting the gradient inherited from the Late-glacial valley to a lower, sea-level influenced, gradient (c. $0.1 \mathrm{~m} \mathrm{~km}^{-1}$ ) of the coastal prism (Van Dijk et al., 1991). The groundwater curves show that by 6000 cal. yr BP the floodbasin gradient had decreased to $c .0 .1 \mathrm{~m} \mathrm{~km}^{-1}$ and has remained constant ever since.

\section{QUANTIFIED DIFFERENTIAL SUBSIDENCE}

Vertical displacements along the inferred fault in the longitudinal section (Fig. 6) are quantified for two stratigraphical levels of known age, respectively the palaeogroundwater level in middle Holocene basal peat (Table 2) and the level of top-of-channel deposits in the LGM (OIS 2) buried terrace (see Table 3).

Table 2 Displacement rates from middle Holocene floodbasin deposits.

(a) Based on offset between two samples*, $0.8 \mathrm{~km}$ apart

\begin{tabular}{|c|c|c|c|c|c|c|c|c|c|c|c|c|c|}
\hline \multirow{2}{*}{$\begin{array}{l}\text { Age } \\
\text { difference } \\
\text { samples } \\
\text { (cal.yr) }\end{array}$} & \multirow{2}{*}{$\begin{array}{l}\text { Age } \\
\text { difference } \\
\text { offset } † \\
(\mathrm{~m})\end{array}$} & \multicolumn{5}{|c|}{$\begin{array}{l}\text { Displacement rate }\left(\mathrm{m} \mathrm{kyr} \mathbf{r}^{-1}\right) \\
\text { assuming groundwater } \\
\text { gradients }\left(\mathrm{m} \mathrm{km}^{-1}\right) \text { of: }\end{array}$} & \multirow{2}{*}{$\begin{array}{l}\text { Age } \\
\text { difference } \\
\text { pair-means } \\
\text { (cal yr) }\end{array}$} & \multirow{2}{*}{$\begin{array}{l}\text { Age } \\
\text { difference } \\
\text { offset } † \\
\text { (m) }\end{array}$} & \multicolumn{5}{|c|}{$\begin{array}{l}\text { Displacement rate }\left(\mathrm{m} \mathrm{kyr} \mathbf{r}^{-1}\right) \\
\text { assuming groundwater } \\
\text { gradients }\left(\mathrm{m} \mathrm{km}^{-1}\right) \text { of: }\end{array}$} \\
\hline & & 0.10 & $0.15 \S$ & $0.20 \S$ & $0.25 \S$ & 0.30 & & & $0.10 \S$ & $0.15 \S$ & $0.20 \S$ & 0.25 & 0.30 \\
\hline 0 & 0.00 & 0.075 & 0.069 & 0.064 & 0.058 & 0.053 & $0 \S$ & $0.00 \S$ & 0.055 & $0.04 I$ & 0.027 & 0.013 & $<0$ \\
\hline $50 \S$ & $0.04 \S$ & 0.069 & 0.064 & 0.058 & 0.053 & 0.047 & $50 \S$ & $0.04 \S$ & 0.049 & 0.035 & 0.021 & 0.007 & $<0$ \\
\hline $100 \S$ & $0.08 \S$ & 0.064 & 0.059 & 0.053 & 0.047 & 0.042 & $100 \S$ & $0.08 \S$ & 0.044 & 0.030 & 0.015 & 0.001 & $<0$ \\
\hline $150 \S$ & $0.12 \S$ & 0.059 & 0.053 & 0.048 & 0.042 & 0.036 & 150 & 0.12 & 0.038 & 0.024 & 0.010 & $<0$ & $<0$ \\
\hline 200 & 0.16 & 0.053 & 0.048 & 0.042 & 0.037 & 0.031 & 200 & 0.16 & 0.032 & 0.018 & 0.004 & $<0$ & $<0$ \\
\hline
\end{tabular}

*Samples 8 and 11; offset 0.62 m; mean age: 7220 cal. yr BP. Downstream sample 8: 7242-7026 cal. BP; 0.87 m OD. Upstream sample 11: 7267-7162 cal. BP; $1.49 \mathrm{~m}$ OD.

‡Sample pairs 8, 10 and 11, 12, offset $0.62 \mathrm{~m}$; mean age: $7100 \mathrm{cal}$. yr BP. Downstream pair 8, 10: 7100 cal. BP; 0.80 m OD. Upstream pair 11, 12: $7100 \mathrm{cal}$. BP; $1.39 \mathrm{~m}$ OD.

tCalculated based on a mean rate of groundwater rise (for 7300-7000 cal. BP) of $0.8 \mathrm{~m} \mathrm{kyr}^{-1}$ (cf. Fig. 7).

§Rows and columns with most realistic estimates. 
Fig. 8 Calculation of the vertical displacement (tectonic offset) in palaeogroundwater levels indicated by the basal peat. The gradient offset and age-difference offset between the groundwater levels were present at the time the peat was formed ('syn-depositional' situation). By subtracting these offsets from the present sample offset ('present' situation), the tectonic offset can be estimated.

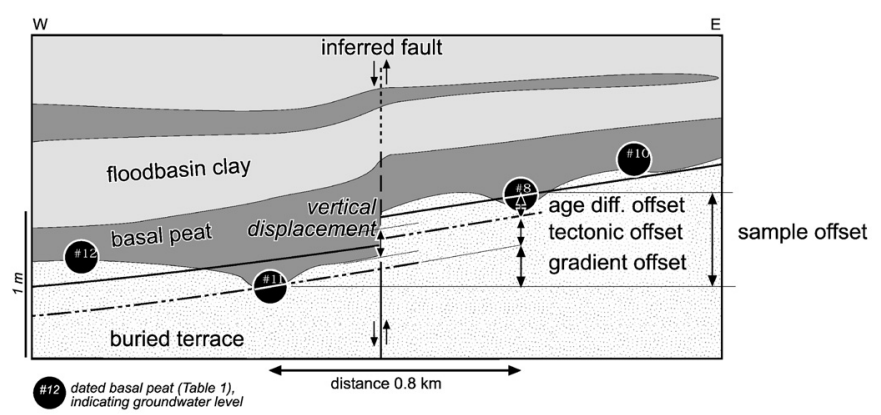

syn-depositional situation

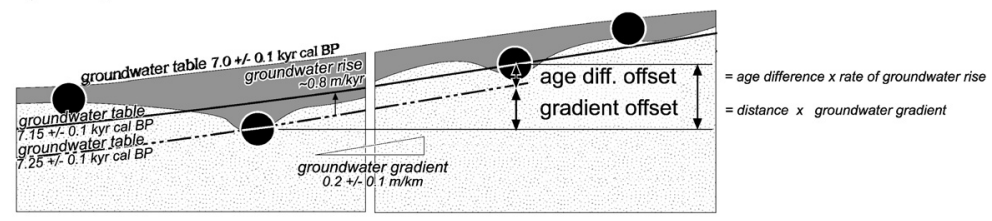

\section{Vertical displacement rates, middle Holocene basal peat}

The elevation difference in the 7300-7000 cal. yr BP basal peat (Figs 6 \& 7: samples 8 and 10-12) is c. $0.60 \mathrm{~m}$, but only part of this difference is a tectonic offset. To calculate fault displacement from the elevation difference between basal peat samples (sample-offset), a correction is made for: (1) the syn-depositional downstream groundwater gradient between the samples, i.e. the 'gradient' offset; and (2) for differences in age between the samples, i.e. the 'age difference' offset (Fig. 8).

1 The gradient offset (Fig. 8) is calculated by multiplying the known sample distance by a presumed gradient. This gradient ranges between the valley gradient $\left(0.30 \mathrm{~m} \mathrm{~km}^{-1}\right)$ of the OIS $2-1$ floodplain and the present $\left(0.10 \mathrm{~m} \mathrm{~km}^{-1}\right)$ groundwater gradient (Van Dijk et al., 1991). The steeper the presumed palaeogroundwater gradient, the lower the displacement rate. Inferring the presence of a fault also introduces the possibility of additional local fault-related hydrological effects. In this case of longitudinal gradients in a fluvial floodbasin, however, with an average groundwater table at/above the surface and with highly permeable sand-gravel on either side of the fault in the first few metres below the surface, such effects could be neglected.
2 The calibrated calendar age ranges of the basal peat dates (samples 8 and 11 in particular) on either side of the fault partly overlap in age range. This may indicate a single palaeogroundwater level (zero age difference), but may also allow for an age difference of up to $200 \mathrm{yr}$. The back-filling setting that caused the peat to form means that it is probable that the downstream sample is older and the upstream sample is younger. For a range of presumed age differences, the 'age difference' offset is calculated by multiplying age-lag with the rate of groundwater rise in the study area $0.8 \mathrm{~m}$ $\mathrm{kyr}^{-1}$ between 7300 and $7000 \mathrm{cal}$. yr BP, based on Fig. 7). A larger presumed age difference yields a lower displacement rate estimate.

Estimates for vertical displacement rates of the basal peat were made for different combinations of values covering a realistic range for groundwater gradient and age difference (Table 2). A first estimate was based on the oldest dates on either side of the inferred fault, samples 8 and 11. Both are from relative lows in the buried LGM (OIS 2) terrace (Fig. 6) and are therefore directly comparable groundwater-index points. Alternatively, an estimate based on the means (age and depth) of sample-pairs on either side of the fault was made for the $7100 \mathrm{cal}$. yr BP groundwater level. This is a slightly younger level compared with the first approach and therefore its groundwater gradient probably was slightly lower. Furthermore, owing 
Table 3 Displacement rates from the Last Glacial Maximum (OIS 2) subsurface.

\begin{tabular}{|c|c|c|c|}
\hline \multirow[b]{2}{*}{ Level of top-of-channel deposits } & \multicolumn{3}{|c|}{$\begin{array}{l}\text { Displacement rate }\left(\mathrm{m} \mathrm{kyr^{-1 } )} \text { assuming age of }\right. \\
\text { abandonment at (cal. kyr BP): }\end{array}$} \\
\hline & 13 & $15^{*}$ & 22 \\
\hline (a) Near-fault subsurface offset: 0.87 m (Fig. 6) & 0.067 & 0.058 & 0.040 \\
\hline \multicolumn{4}{|l|}{$0.80 \mathrm{~m}$ OD (two cores, within $200 \mathrm{~m}$ upstream of fault) } \\
\hline \multicolumn{4}{|l|}{1.67 m OD (four cores, within 200 m downstream of fault) } \\
\hline (b) Gradient line offset: 0.55 m (Fig. 9) & 0.042 & 0.037 & 0.025 \\
\hline \multicolumn{4}{|l|}{$0.45 \mathrm{~m}$ OD (62 cores, within $2.5 \mathrm{~km}$ upstream of fault) } \\
\hline I.00 m OD (I 35 cores, within 5 km downstream of fault) & & & \\
\hline
\end{tabular}

*Most realistic value.

to the averaging of sample-pairs, the age difference also is less than in the first approach. Hence, in Table $2 \mathrm{~b}$, gradients exceeding $0.25 \mathrm{~m} \mathrm{~km}^{-1}$ and age differences exceeding $150 \mathrm{yr}$ are not realistic assumptions, and yield negative values (technically implying reverse movement along the fault). Realistic values for displacement rates ranged between 0.03 and $0.07 \mathrm{~m} \mathrm{kyr}^{-1}$ (Table 2), averaged over the past $7 \mathrm{kyr}$. They imply that $0.2-0.4 \mathrm{~m}$ of total relative displacement occurred, which is $5-10 \%$ of the $5 \mathrm{~m}$ of total aggradation just downstream of the inferred fault (Fig. 6).

Diverging groundwater-level curves (Fig. 7) may be an indication of differential subsidence (Fig. 2C). The resolution of basal-peat groundwater index points (depth error $c .0 .20 \mathrm{~m}$ ) only allows comparison of differential effects between older parts of the curves, which have been exposed to low postdepositional differential rates (c. $0.06 \mathrm{~m} \mathrm{kyr}^{-1}$ ) long enough (>5 kyr) to be displaced by a significant amount $(>0.30 \mathrm{~m})$. The 'upstream' and 'central' curves (Fig. 7) are based on the basal peat sample-pairs of the longitudinal section (Fig. 6). These curves do not span a wide enough temporal range to show clear divergence back in time. The older parts of the groundwater-level curves of the dune sites (7500-6000 cal. yr BP) do diverge back in time. As discussed above, this is mainly the result of the variable groundwater gradient (the older the samples, the steeper the floodbasin gradient and therefore the greater their difference in depth), but the divergence may also include some differential subsidence.

\section{Vertical displacement rates, Last Glacial Maximum (OIS 2) subsurface}

The offset in the top of the buried LGM terrace in Fig. 6 is c. $0.9 \mathrm{~m}$, based on the descriptions of the boreholes within $200 \mathrm{~m}$ of the fault. An age of abandonment of 15 cal. yr BP is presumed for this terrace, which is consistent with available dating evidence (radiocarbon, OSL, palaeosols, pollen; Verbraeck, 1984; De Jong, 1995; Törnqvist et al., 2000; Wallinga, 2001; Berendsen \& Stouthamer, 2001; Cohen et al., 2002). The maximum estimate for vertical displacement rates along the inferred fault is $C .0 .06 \mathrm{~m} \mathrm{kyr}^{-1}$ over the past $15 \mathrm{kyr}$ (Table 3). Alternatively, the offset may be calculated from the analysis of longitudinal profiles of the top of Late-glacial sand, as recorded in 197 cores that penetrated the surface of the buried LGM terrace. The local offset (cf. Cohen et al., 2002) calculated from this gradient line is $c .0 .55 \mathrm{~m}$ (Fig. 9), 33\% less than the offset found in the longitudinal section (Fig. 6). The slope upstream of the inferred fault $\left(0.33 \mathrm{~m} \mathrm{~km}^{-1}\right)$ is steeper than downstream $\left(0.17 \mathrm{~m} \mathrm{~km}^{-1}\right)$. These values are respectively high and low, compared with the regional slope of the buried LGM terrace ( $c$. 0.20-0.30 m km $\mathrm{m}^{-1}$; Berendsen \& Stouthamer, 2001). Steep upstream slopes and gentle downstream slopes in the longitudinal profiles of the Late-glacial valley are also observed further south across the PBF (Stouthamer \& Berendsen, 2001; Cohen et al., 2002). Syn-depositional tectonics might explain the lower gradient of the faster 
Fig. 9 Elevation and position of top-of-channel deposits in the Last Glacial Maximum (OIS 2) terrace relative to the inferred fault. Plotted is the highest occurrence of fluvial sand (top of channel deposits) in 197 boreholes that reached the LGM terrace and that are within $2 \mathrm{~km}$ lateral distance of the longitudinal section (Fig. 6), projected on a longitudinal axis perpendicular to the inferred fault. The standard deviation (relative to the downstream trend) in the elevation of the top of channel deposits is $0.42 \mathrm{~m}$. A displaced gradient line for the top of the LGM surface is drawn based on local maxima in the data points, which represent bar tops. The fault offset estimated from this gradient line is $c .0 .55 \mathrm{~m}$.

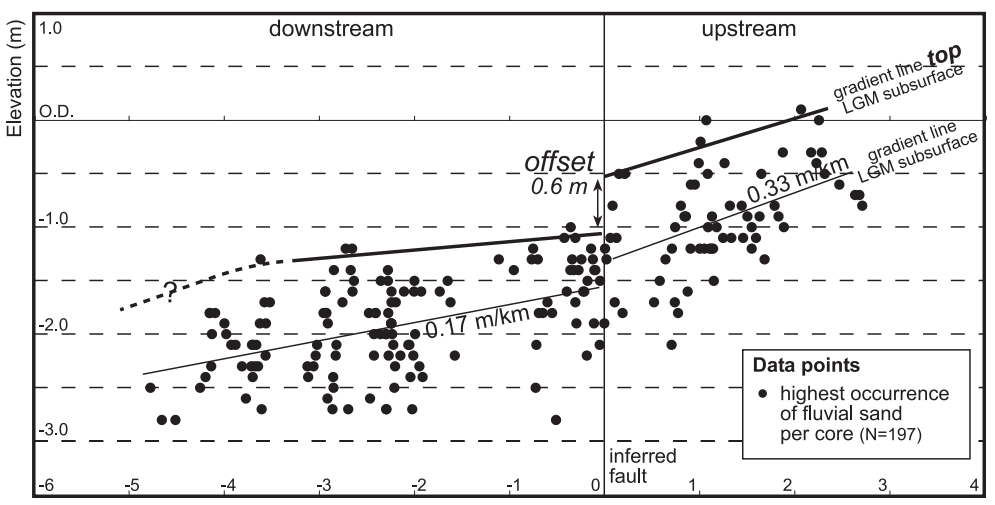

Longitudinal position $(\mathrm{km}$, fault $=0)$ subsiding downstream hanging wall (Fig. 2A), indicating that differential subsidence across the PBF was an active control in the LGM Rhine valley too. The present slope, however, is not necessarily identical to the river gradient during deposition (Cohen et al., 2002). Post-depositional tectonic deformation along unrecognized faults, tilting of blocks, and tectonic warping without faulting, may have changed the original slope. The gentle slope downstream of the fault may be caused by post-depositional back tilting, and may indicate that main subsidence occurred directly downstream of the fault whereas further downstream subsidence was less. This is not uncommon for fault zones, and would also explain why estimates of fault displacement based on basal peat and the buried terrace surface within a few hundred metres upstream and downstream of the fault yield higher values (Tables 2a \& 3a) than estimates based on data selected over longer distances (Tables 2b \& 3b).

\section{Absolute subsidence rates}

Subsidence rates were quantified from the relative rise of groundwater at the buried dune sites 'Zandberg' and 'Treeft' (Fig. 7). Rates of middlelate Holocene floodbasin aggradation at these sites approach rates of relative sea-level rise. Maximum rates of $2.0 \mathrm{~m} \mathrm{kyr}^{-1}$ were reached $6500-6000 \mathrm{cal}$. yr
BP. After 5500 cal. yr BP these decreased rapidly to $C .0 .5 \mathrm{~m} \mathrm{kyr}^{-1}$. The latter rates are typical of areas of subsidence: global eustatic sea-level rise decreased to virtually zero, but subsidence continued to create accommodation space. Like relative sea-level rise, groundwater-level rise can be separated into a subsidence component (lowering the surface below the water table) and a component of absolute groundwater-table rise (controlled by either downstream eustatic sea-level rise or upstream 'climatic' changes in discharge). Groundwater-level gradients have been constant during the middle Holocene (Van Dijk et al., 1991), so the component of absolute groundwater level was spatially constant. Aggradation between 7000 and $5500 \mathrm{cal}$. yr BP at 'Treeft' dune site, however, exceeds that of relative sea-level rise (Van de Plassche, 1982; inset Fig. 7). Hence, during this period, local subsidence must have exceeded subsidence in the coastal area.

A significant effect of changes in upstream discharge on groundwater levels is not recorded in the basal peat record, but is suspected after 4000 cal. yr BP, when peat formation terminates in favour of clay deposition. Subrecent (after 4000 cal. yr BP) aggradation rates are linear and slightly greater at the coast than in the study area (respectively c. 0.7 and $\quad$ c. $0.5 \mathrm{~m} \mathrm{kyr}^{-1}$ ). These values suggest that subrecent subsidence was greater at the coast and that upstream controls did 
not add significantly to aggradation in the study area. Presuming zero eustatic sea-level rise since 4000 cal. yr BP, subrecent rates can be seen as maximum estimates of absolute subsidence. A more realistic estimate accounts for some eustatic rise ('melting tail', most probably $\leq 0.25 \mathrm{~m} \mathrm{kyr}^{-1}$ sea-level rise; Peltier, 2002) and effects of upstream discharge change, leaving $0.2-0.4 \mathrm{~m} \mathrm{kyr}^{-1}$ of the total $0.5 \mathrm{~m} \mathrm{kyr}^{-1}$ to attribute to subsidence. Combining this rate with the differential subsidence $\left(0.03-0.07 \mathrm{~m} \mathrm{kyr}^{-1}\right)$ within the study area suggests that subsidence upstream of the inferred fault was $10-35 \%$ less than downstream.

\section{DISCUSSION}

The control of active tectonics on alluvial rivers has long been recognized (Schumm et al., 2000), and specific studies of syn-depositional fluvial response to tectonics are no longer rare. So far, syn-depositional response of active channels has been described in explorative studies, mapping changes of in-channel morphology of active rivers over different tectonic reaches of their alluvial valley. Fluvio-deltaic systems are usually excluded from these studies, because the sedimentary architecture there is primarily attributed to downstream controls (i.e. tides, storms, sea-level rise). Studies focusing on tectonics in overbank sediments of alluvial valley floodplains (such as the New Madrid Seismic Zone (NMSZ) in the Mississippi valley; Guccione et al., 2002) or deltaic floodbasins (such as this study) are still rare. Yet, deltaic systems have low-gradient reaches, and low-gradient channels are believed to be most sensitive to subtle neotectonic deformation (Holbrook \& Schumm, 1999), and their Holocene records, particularly in the floodbasins, are relatively continuous and complete.

\section{Local synsedimentary response and linearity of tectonic deformation}

In the study area, both in the middle Holocene (rapid aggradation) and in the late Holocene (slower aggradation), crevasse splays preferentially developed downstream of the inferred fault, so the spatial distribution of the splays reflects the difference in subsidence rates. Linearly averaged over the middle-late Holocene, rates of differential subsidence are very low $\left(<0.07 \mathrm{~m} \mathrm{kyr}^{-1}\right)$ and it is unlikely that, in reality, gradual deformation (tectonic creep) could have had such a persistent effect on crevasse-splay locations. Probably, most of the middle-late Holocene offset is essentially related to a shorter period of high fault activity. Given the observation that 7000-5500 cal. yr BP subsidence was greater in the study area than at the coast, whereas for the remaining Holocene it was not, the $0.20-0.40 \mathrm{~m}$ offset is probably related to displacement (tentatively related to PBF earthquakes driving fault offset) at this time. This activity may have caused significant lowering downstream of the fault, followed by the development of crevasse splays. As these splays cover basal peat, subsequent autocompaction (Allen, 1999) may have further amplified this response to tectonics in the floodbasin architecture. Effects of major middle Holocene displacement will not have been limited to the study area and may also have favoured middle Holocene avulsions at the delta's main nodal avulsion site (Wijk bij Duurstede, Fig. 3) directly to the north (Stouthamer \& Berendsen, 2000).

\section{Deglaciation-related tectonic activity}

Although Holocene syn-depositional evidence points to non-linear displacement rates across the PBF, post-depositional offsets since $15 \mathrm{ka}$ and 7000 cal. yr BP give roughly similar rates, pointing to linearity over the full time-scale of this study. In addition to normal extensional tectonics of the RVG (Houtgast \& Van Balen, 2000), Lateglacial fault activity might have been increased owing to forebulge collapse (Lambeck et al., 1998; Van den Berg et al., 2002; Cohen et al., 2002). In that case, high Late-glacial rates, decreasing towards the Holocene, can be expected. Accepting a middle Holocene event causing most of the post 7 ka displacement would imply that the last major event occurred roughly 6000 yr ago. Apart from normal tectonics and forebulge collapse, this last activity also might be (partially) attributed to loading by the filling North Sea and aggrading coastal prism (hydro-isostasy; Lambeck et al., 1998; Peltier, 2002) At the present coast this started in the early-middle Holocene (Stanley \& Warne, 1994) and thus lags Late-glacial forebulge 
collapse. Thus, although the syn-sedimentary effect of differential subsidence is independent of deglaciation-related controls, such as upstream climate change and sea-level rise, the timing of tectonic events causing post-depositional deformation might be related.

\section{Coastal-prism differential subsidence}

Coastal areas at the edge of sedimentary basins are areas of subsidence, and the build-up of coastal prisms by low-gradient rivers has continued over the second half of the Holocene (Posamentier et al., 1992; Stanley \& Warne, 1994; Talling, 1998), despite the dramatic decrease in eustatic-driven sea-level rise. Subsidence rates can vary along the longitudinal profile of deltaic rivers, whereas there is only one rate of eustatic base-level rise for the entire coastal prism. This results in spatially variable sedimentary response to water-level rise. Many coastal prisms, in particular those of larger rivers, are aligned with the tectonic structure (e.g. Mississippi River, Po River, Orinoco River). In these cases, variation in subsidence along the delta axis is gradual, and differential subsidence will be hardly recognizable as an independent control. The glacially imposed valley of the Rhine, however, crosses the structural trend, which results in an abrupt downstream increase in subsidence. Hence significant syn-depositional effects in floodbasin architecture occurred, and tectonics may be identified as an independent local control on fluvio-deltaic deposition. This control locally affected aggradation rates and crevasse-splay development (this study) and regionally affected avulsion (Berendsen \& Stouthamer, 2000).

Similar syn-depositional controls on floodbasin architecture have been identified in alluvial valley settings. For example, in the New Madrid Seismic Zone a crevasse splay has been documented that preferentially developed in the down-warped area directly north-east of the Lake County Uplift (Guccione et al., 2002), and within the Okavango Fan panhandle-region, the transition from meandering to avulsive anastomozing reaches has been related to the activity of the upstream fault-zone of a subsurface graben (Smith et al., 1997). The present study shows that across active normal faults, rivers in their deltaic reaches experience similar tectonic controls to those identified in alluvial valleys. Despite the strong sea-level control on the back-filling coastal prism reaches, the floodbasin faithfully records a tectonic component. Within the Lower Mississippi valley, given the distance to the river mouth, the South Louisiana Growth Fault region around Baton Rouge (Autin et al., 1991) might allow a direct comparison with this study. The tectonic control identified in the Rhine-Meuse delta may be of importance in many other high-stand coastal prisms.

\section{CONCLUSIONS}

The Holocene fluvial record in the study area reflects the tectonic control of differential subsidence on floodbasin aggradation. The location of an active fault belonging to the Peel Boundary Faultzone (PBF) could be inferred from longitudinal changes in sedimentary facies, from deformation in sedimentary surfaces and from the analysis of dated basal peats as palaeogroundwater-level indicators. Differential subsidence was quantified from fault-related post-depositional vertical displacement of surfaces of known age (c. $0.9 \mathrm{~m}$ in the Last Glacial Maximum subsurface and 0.2$0.4 \mathrm{~m}$ in the middle Holocene basal peat, yielding 7 to $15 \mathrm{ka}$ averaged rates of $0.03-0.07 \mathrm{~m} \mathrm{kyr}^{-1}$ ). High rates of subsidence between 7000 and 5500 cal. yr BP, together with sedimentological evidence of syn-depositional fault activity, suggest that the last major offset along this fault of the PBF occurred in the middle Holocene, and hence differential subsidence occurs at non-linear rates over time-scales $<7$ kyr.

This study shows that active tectonics may cause syn-sedimentary response in coastal prism deltas, just like in alluvial valleys. Despite the strong sea-level control, aggrading deltaic floodbasins may record tectonics locally because subsidence rates across faults vary, whereas rates of eustatic/climatic base-level rise are uniform across the entire coastal prism. This implies that back-filling should not solely be attributed to downstream relative sea-level rise dominating upstream deposition, but that local differential subsidence must be considered as an additional independent control. The timing of tectonic events in coastal prisms, however, is not necessarily independent of sea-level rise, and models coupling coastal- 
prism fault activity to hydro-glacioisostasy should be considered.

\section{ACKNOWLEDGEMENTS}

We thank all the people who helped during our fieldwork in the study area, in particular M. Van Ree who prepared the basal peat samples and A.W. Hesselink who provided a cross-section through the 'River Lek' embanked floodplain to complete Fig. 4. The longitudinal section (Fig. 6) was presented at the session on 'Alluvial and tectonic system interactions' at the 7th International Congress of Fluvial Sedimentology (Nebraska, USA, 2001). This paper benefited from discussions at the conference and during the pre-conference fieldtrip along the Mississippi, including the New Madrid Seismic Zone, so all participants are thanked. Reviewers J. Alexander and A.E. Mather as well as editor M.D. Blum are thanked for their good comments. This research is part of a $\mathrm{PhD}$ project 'Neotectonics in the Rhine-Meuse delta', sponsored by the Netherlands Organisation for Scientific Research (NWO)-Earth and Life Sciences (ALW).

\section{REFERENCES}

Ahorner, L. (1992) Das Erdbeben bei Roermond am 13. April 1992. Bericht der Abteilung für Erdbebengeologie des Geologischen Instituts der Universität zu Köln, Bensberg, 11 pp.

Allen, J.R.L. (1999) Geological impacts on coastal wetland landscapes: some general effects on sediment autocompaction in the Holocene of northwest Europe. The Holocene, 9(1), 1-12.

Autin, W.J., Burns, S.F., Miller, B.J., Saucier, R.T. and Snead, J.I. (1991) Quaternary geology of the Lower Mississippi Valley. In: Quaternary Nonglacial Geology, Conterminous United States (Ed. R.B. Morrison). The Geology of North America, Vol. K-2, pp. 547-582. Geological Society of America, Boulder, CO.

Alexandre, P. (1994) Historical seismicity of the lower Rhine and Meuse valleys from 600 to 1525: a new critical review. Geol. Mijnbouw, 73, 431-438.

Berendsen, H., Hoek, W. and Schorn, E. (1995) Late Weichselian and Holocene river channel changes of the rivers Rhine and Meuse in the Netherlands (Land van Maas en Waal). In: European River Activity and Climate Change during the Lateglacial and Holocene
(Eds B. Frenzel, J. Vandenberghe, C. Kasse, S. Bohncke and B. Gläser). Paläoklimaforschung/Paleoclim. Res., 14, 151-172.

Berendsen, H.J.A. and Stouthamer, E. (2000) Late Weichselian and Holocene palaeogeography of the Rhine-Meuse delta, The Netherlands. Palaeogeogr., Palaeoclimatol., Palaeoecol., 161, 311-335.

Berendsen, H.J.A. and Stouthamer, E. (2001) Palaeogeographical Development of the Rhine-Meuse Delta, The Netherlands. Van Gorcum, Assen, 268 pp.

Blum, M.D. and Törnqvist, T.E. (2000) Fluvial response to climate and sea level change: a review and look forward. Sedimentology, 47, 2-48.

Bronk Ramsey, C. (1995) Radiocarbon calibration and analysis of stratigraphy: the OxCal program. Radiocarbon, 37, 425-430.

Camelbeeck, T. and Meghraoui, M. (1998) Geological and geophysical evidence for large palaeo-earthquakes with surface faulting in the Roer Graben (northwest Europe). Geophys. J. Int., 132, 347-362.

Cohen, K.M. (2003) Differential subsidence within a coastal prism. Published PhD thesis, Department of Physical Geography, Utrecht University. Neth. Geogr. Stud., 316, 176 pp.

Cohen, K.M., Stouthamer, E. and Berendsen, H.J.A. (2002) Fluvial deposits as a record for Late Quaternary neotectonic activity in the Rhine-Meuse delta, The Netherlands. Neth. J. Geosci./Geol. Mijnbouw, 81(3/4), $389-405$.

De Jong, J. (1995) Some palaeobotanical data on the fluviatile Rhine/Meuse Kreftenheye Formation in the Netherlands (Weichselian). In: Neogene and Quaternary Geology of North-west Europe (Eds G.F.W. Herngreen and L. Van der Valk). Med. Rijks Geol. Dienst, 52, 369-385.

De Vries, J.J. (1974) Groundwater flow systems and stream nets in The Netherlands. PhD thesis, Free University Amsterdam, $226 \mathrm{pp}$.

Geluk, M.C., Duin, E.J.Th., Dusar, M., Rijkers, R.H.B., Van den Berg, M.W. and Van Rooijen, P. (1994) Stratigraphy and tectonics of the Roer Valley Graben. Geol. Mijnbouw, 73, 129-141.

Gibbard, P.L. (1995) The formation of the Strait of Dover. In: Island Britain: a Quaternary Perspective (Ed. R.C. Preece). Geol. Soc. Lond. Spec. Publ., 96, $15-26$.

Guccione, M.J., Mueller, K., Champion, J. Shepherd, S., Carlson, S.D., Odhiambo, B. and Tate, A. (2002) Stream response to repeated coseismic folding, Tiptonville dome, New Madrid seismic zone. Geomorphology, 43, 313-349.

Hofstede, J.L.A., Berendsen, H.J.A. and Janssen, C.R. (1989) Holocene palaeogeography and palaeoecology of the fluvial area near Maurik (Neder-Betuwe, The Netherlands). Geol. Mijnbouw, 68, 409-419.

Holbrook, J. and Schumm, S.A. (1999) Geomorphic and sedimentary response of rivers to tectonic deforma- 
tion: a brief review and critique of a tool for recognizing subtle epeirogenic deformation in modern and ancient settings. Tectonophysics, 305, 287-306.

Houtgast, R.F. and Van Balen, R.T. (2000) Neotectonics of the Roer Valley Rift System, The Netherlands. Global Planet. Change, 27, 131-146.

Houtgast, R.F., Van Balen, R.T., Bouwer, L.M., Brand, G.B.M. and Brijker, J.M. (2002) Late Quaternary activity of the Feldbiss Fault zone, Roer Valley Rift System, The Netherlands, based on displaced fluvial terrace fragments. Tectonophysics, 352, 295-315.

Huisink, M. (1997) Lateglacial sedimentological and morphological changes in a lowland river in response to climate change: the Maas, southern Netherlands. J. Quat. Sci., 12, 209-223.

Jelgersma, S. (1961) Holocene sea-level changes in The Netherlands. PhD thesis, University Leiden. Med. Geol. Sticht., CVI-1.

Lehrman, K., Klostermann, J. and Pelzing, R. (2001) Paleoseismological investigations ate the Rurrand Fault, Lower Rhine Embayment. Netherlands J. Geosci./Geol. Mijnbouw, 80, 139-154.

Kasse, C. (1995) Younger Dryas cooling and fluvial response (Maas River, The Netherlands) (extended abstract). Geol. Mijnbouw, 74, 251-256.

Klostermann, J. (1992) Das Quartär der Niederrheinische Bucht. Geologisches Landesamt NordrheinWestfalen, Krefeld, 200 pp.

Lambeck, K., Smither, C. and Johnston, P. (1998) Sealevel change, glacial rebound and mantle viscosity for northern Europe. Geophys. J. Int., 134, 102-144.

Makaske, B. (1998) Anastomosing rivers. Forms, processes and sediments. PhD thesis. Utrecht University (Utrecht). Ned. Geogr. Stud., 249, 298 pp.

Martinson, D.G., Pisias, N.G., Hays, J.D., Imbrie, J., Moore, T.C. and Shackleton, N.J. (1987) Age dating and the orbital theory of the Ice Ages: development of a high resolution 0 to 300 000-year chronostratigraphy. Quat. Res., 27, 1-29.

Peltier, W.R. (2002) On eustatic sea level history: Last Glacial Maximum to Holocene. Quat. Sci. Rev., 21, 377-396.

Posamentier, H.W., Allen, H.W., James, D.P. and Tesson, M. (1992) Forced regressions in a sequence stratigraphic framework: Concepts, examples, and sequence stratigraphic significance. Am. Assoc. Petrol. Geol. Bull., 76, 1687-1709.

Schumm, S.A., Dumont, J.F. and Holbrook, J.M. (2000) Active Tectonics and Alluvial Rivers. Cambridge University Press, Cambridge, 276 pp.

Stanley, D.J. and Warne, A.G. (1994) Worldwide initiation of Holocene marine deltas by deceleration of sea-level rise. Science, 265, 228-231.

Smith, N.D., McCarthy, T.S., Ellery, W.N., Merry, C.L. and Rüther, H. (1997) Avulsion and anastomosis in the panhandle region of the Okavango Fan, Botswana. Geomorphology, 20, 49-65.
Stouthamer, E. (2001) Holocene avulsions in the Rhine-Meuse delta, The Netherlands. PhD thesis, Utrecht University. Ned. Geogr. Stud., 283, 212 pp.

Stouthamer, E. and Berendsen, H.J.A. (2000) Factors controlling the Holocene avulsion history of the Rhine-Meuse delta (The Netherlands). J. Sediment. Res. Section A, 70(5), 1051-1064.

Stuiver, M., Reimer, P.J., Bard, E., Beck, J.W., Burr, G.S., Hughen, K.A., Kromer, B., McCormac, F.G., Van der Plicht, J. and Spurk, M. (1998) INTCAL98 Radiocarbon age calibration 24,000-0 cal BP. Radiocarbon, 40, 1041-1083.

Talling, P.J. (1998) How and where do incised valleys form if sea level remains above the shelf edge? Geology, 26, 87-90.

Tebbens, L.A., Veldkamp, A., Westerhoff, W. and Kroonenberg, S.B. (1999) Fluvial incision and channel downcutting as a response to Late-glacial and Early Holocene climate change: the lower reach of the River Meuse (Maas), the Netherlands. J. Quat. Sci., 14, 5975 .

Tebbens, L.A., Veldkamp, A., Westerhoff, W. and Kroonenberg, S.B. (2000) Reply: Fluvial incision and channel downcutting as a response to Late-glacial and Early Holocene climate change: the lower reach of the River Meuse (Maas), the Netherlands. Correspondence. J. Quat. Sci., 15, 95-100.

Törnqvist, T.E. (1993) Holocene alternation of meandering and anastomosing fluvial systems in the Rhine-Meuse delta (central Netherlands) controlled by sea-level rise and subsoil erodibility. J. Sediment. Petrol., 63, 683-693.

Törnqvist, T.E., Weerts, H.J.T. and Berendsen, H.J.A. (1994) Definition of two new members in the upper Kreftenheye and Twente formations (Quaternary, the Netherlands): a final solution to persistent confusion? Geol. Mijnbouw, 72, 251-264.

Törnqvist, T.E., Van Ree, M.H.M., Van 't Veer, R. and Van Geel, B. (1998) Improving methodology for high-resolution reconstruction of sea-level rise and neotectonics by paleoecological analysis and AMS ${ }^{14} \mathrm{C}$ dating of basal peats. Quat. Res., 49, 72-85.

Törnqvist, T.E., Wallinga, J., Murray, A.S., De Wolf, H., Cleveringa, P. and De Gans, W. (2000) Response of the Rhine-Meuse system (West-central Netherlands) to the last Quaternary glacio-eustatic cycles: a first assessment. Global Planet. Change, 27, 89-111.

Van Dijk, G.J., Berendsen, H.J.A. and Roeleveld, W. (1991) Holocene water level development in The Netherlands' river area; implications for sea-level reconstruction. Geol. Mijnbouw, 70, 311-326.

Van de Plassche, O. (1982) Sea-level change and water level movements in the Netherlands during the Holocene. Mededelingen Rijks Geologische Dienst, 36, $93 \mathrm{pp}$.

Van den Berg, M.W. (1994) Neotectonics of the Roer Valley rift system. Style and rate of crustal deforma- 
tion inferred from syn-tectonic sedimentation. Geol. Mijnbouw, 73, 143-156.

Van den Berg, M.W., Groenewoud, W., Lorenz, G.K., Brus, D.J. and Kroonenberg, S.B. (1994) Patterns and velocities of recent crustal movements in the Dutch part of the Roer Valley rift system. Geol. Mijnbouw, 73, 157-168.

Van den Berg, M.W., Vanneste, K., Dost, B., Lokhorst, A., Van Eijk, M. and Verbeeck, K. (2002) Paleoseismic investigations along the Peel Boundary Fault: geologic setting, site selection and trenching results. Neth. J. Geosci./Geol. Mijnbouw, 81, 39-60.

Van Montfrans, H.M. (1975) Toelichting bij de ondiepe breuken kaart met de diepte van de formatie van Maassluis 1 : 600 000. In: Toelichtingen bij de geologische overzichtskaarten van Nederland (Eds W.H. Zagwijn and C.J. Van Staalduijnen), pp. 103-109. Rijks Geologische Dienst, Haarlem.

Vanneste, K., Meghraoui, M. and Camelbeeck, T. (1999) Late Quaternary earthquake related soft-sediment deformation along the Belgian portion of the Feldbiss Fault, Lower Rhine Graben system. Tectonophysics, 309, 57-79.
Verbraeck, A. (1984) Toelichtingen bij de Geologische kaart van Nederland 1 :50.000, Blad 39, Tiel West, Tiel Oost. Rijks Geologische Dienst, Haarlem, $325 \mathrm{pp}$.

Verbraeck, A. (1990) De Rijn aan het einde van de laatste ijstijd: De vorming van de jongere afzettingen van de Formatie van Kreftenheye. Geogr. Tijds. Nieuwe Reeks, XXIV(4), 328-340.

Walker, M.J.C., Björck, S., Lowe, J.J., Cwynar, L.C., Johnsen, S., Knudsen, K.-L., Wohlfarth, B. and INTIMATE group (1999) Isotopic 'events' in the GRIP ice core: a stratotype for the Late Pleistocene. Quat. Sci. Rev., 18, 1143-1150.

Wallinga, J. (2001) The Rhine-Meuse system in a new light: optically stimulated luminescence dating and its application to fluvial deposits. PhD thesis. Utrecht University. Ned. Geogr. Stud., 290, 180 pp.

Zagwijn, W.H. (1989) The Netherlands during the Tertiary and the Quaternary: A case history of Coastal Lowland evolution. Geol. Mijnbouw, 68, 107-120.

Zagwijn, W.H. and Van Staalduinen, C.J. (Eds) (1975) Toelichtingen bij de geologische overzichtskaarten van Nederland. Rijks Geologische Dienst, Haarlem. 